\title{
A bábamesterség átalakulása a XX. század közepén
}

\author{
SVÉGEL FANNI \\ Eötvös Loránd Tudományegyetem Bölcsészettudományi Kar, Néprajzi Intézet, \\ e-mail: fanni.svegel@hotmail.com
}

\begin{abstract}
SVÉGEL, F.: The transformation of midwifery in the middle of the $X X^{\text {th }}$ century.

Abstract: In this paper an analysis of the transformation of hungarian birth culture and midwifery are given. The research is based on the professional objects and diaries of a midwife from Rinyaújlak, Somogy County (now the property of the City Museum of Nagyatád) and on interviews with a midwife from Nagyatád. The main argument of the paper is that in the middle of the last century a hybrid birth culture can be observed that is a mixture of traditional midwifery and the modern medicalized culture of birth identified with hospital care.
\end{abstract}

Keywords: birth culture, medicalization, institutionalization, biopolitics

\section{Bevezetés}

Jelen tanulmány az ELTE Néprajzi Intézetében 2018ban megvédett szakdolgozatomon alapul, annak rövidített, főként a lokális specifikumokra koncentráló változata. A problémát tágabb, elméleti kontextusba helyező fejezetek - terjedelmi okokból - nem kerültek be a kiadványba. A továbbiakban Somogy megye területén, a XX. században élő és dolgozó bábák szakmai pályafutásának tárgyalására kerül sor. Munkám elsősorban a nagyatádi helytörténeti forrásokra és szakirodalmi anyaggyűjtésre támaszkodik, kiegészülve múzeumi és levéltári kutatással, valamint interjúkészítéssel. Egy tárgyi emlékek alapján rekonstruált életút és egy személyesen elbeszélt élettörténet (konstruált múlt) az ötvenes évek elején találkozik és fonódik egymásba. Arra teszek kísérletet, hogy tetten érjem két somogyi bábaasszony munkásságában a század közepén a szülészetben lezajlott radikális változásokat (otthonról a szülöotthonba, szülöotthonból a kórházba) és ezeknek társadalmi-kulturális vonzatait. A tárgyi és írásos emlékek segítenek megválaszolni a lokális gyakorlatra vonatkozó kérdéseket. Mi olvasható ki a bábanaplókból? Milyen szemléletmódot képviseltek a somogyi bábák és milyen eszköztárral dolgoztak?

Kiindulási pontként az a gondolat szolgál, miszerint a XX. században erőteljesen lecsökkent azon parasztbábák száma, akiket a régebbi korok néprajzi leírásaiból megismerhetünk. ${ }^{1}$ A bábaképzés XVIII. századi intézményesülése a bábák képzettség szerinti rétegződését hívta életre. ${ }^{2}$ Látnunk kell, hogy az okleveles és a parasztbábák közötti konfliktus legalább olyan erős - ha nem erősebb - volt, mint a korabeli megélhetésért folytatott küzdelem bábák és orvosok között. A falusi kö-

Deáky Zita hívja fel rá a figyelmet, hogy még az 1990-es években is müködtek parasztbábák moldvai falvakban. Deáky 1999. 51.

2 Deáky 1996. 161 zösségek bizalmatlansága a - hivatalosságot képviselő - tanult bábák iránt nem könnyítette meg helyzetüket. Kívülállóságának kettős mivoltáról tanúskodik, hogy nem csak a közösség, de az orvostársadalom sem tekintette a bábát köreikbe tartozónak. Mindebböl az is kiviláglik, hogy amikor a XVIII. - XX. századi „bábákról” beszélünk, szem előtt kell tartanunk, hogy egy erősen rétegzett, hierarchizált - belső ellentétektől egyáltalán nem mentes - társadalmi csoportról van szó. ${ }^{3}$

Magát a szülés aktusát mindig is tabuk vették körül, de a XX. század közepén bevezetett kötelező kórházi szülések megjelenésével megváltozik ezek jellege. ${ }^{4}$ Már nem arról van szó, hogy a férfiak kizárásával a nők maguk közt örökítik tovább a - néha hiányos, néha téves - tudást. A bábák folyamatos szakmai háttérbe szorulásával és a szülészorvosok autoritásának növekedésével a női anatómiáról és reprodukciós funkciókról szóló ismeret a férfiak monopóliumává válik. Ez a folyamat már a XVIII. században elkezdődik, viszont nagy változatosságot mutat mind európai, mind magyarországi szinten. ${ }^{5}$ Le kell hát mondanunk a progresszív, lineáris fejlődés gondolatában gyökerező megnyugtató magyarázatokról és fel kell ismernünk a dinamikus folyamatok jelenlétét, annak minden ellentmondásával és bonyolultságával.

Nem szabad figyelmen kívül hagynunk, hogy a hivatalos szemléletmód mellett még erősen élt a tanult bábák közt is a hagyományokhoz való ragaszkodás. Így fordulhatott elő, hogy okleveles bábák az orvostársadalom által kuruzslásnak minősített módszerekhez folyamodtak. ${ }^{6}$ Azok a bábaasszonyok, akik még házhoz jártak a szülésekhez valamivel nagyobb személyes szabadságot engedhettek meg maguknak annak kapcsán mi, mikor és hogyan történik a szülés alatt. A közösségi normákhoz és elvárásokhoz igazodva végezték hivatásukat, ellentétben azokkal, akik már szülőotthonokban dolgoztak. Az ő munkamódszerüket nagyban befolyásolta az oktatás során beléjük nevelt és az intézményi háttér által megerősített és szentesített hivatalos narratíva. Azonban számolnunk kell azzal a körülménnyel, hogy az idősebb bábák még intézményi dolgozóként is ragaszkodtak a hagyományokhoz. Ezt támasztják alá a szükségkeresztség elvégzésére vonatkozó fennmaradt adatok is. ${ }^{7}$

\footnotetext{
3 Deáky 1996. 163.

4 Deáky 2005. 70.

5 Lásd Krász Lilla témában megjelent publikációit.

6 Deáky 1994. 426.

7 A szükségkeresztelés még az 1980-as években is előfordult az egészségügyi intézményekben. Kapros 1986. 223., Deáky 1999. 51., Deáky - Krász 2005. 281. Az egyházi álláspont történeti változásairól lásd: Bárth 2005. 160-165.
} 
Az ötvenes évek több szempontból is meghatározónak bizonyult a nők életében: jelentősen megnőtt a szülőotthonok, majd a kórházi szülészetek száma. Ennek következtében az emberi élet fordulóihoz kapcsolódó első átmeneti rítus - a születés - kiszakadt a megszokott, otthoni környezetböl és áthelyeződött a szülő nők számára ismeretlen helyre, ami számos rítuselem megszűnését eredményezte, mivel a kórházi közeg nem tette lehetővé azok gyakorlását. Ehhez kapcsolódóan kell feltennünk a kérdést, hogy pontosan miként zajlottak a szülések a nagyatádi szülőotthonban, majd a kórházban. Felfedezhetők-e a hagyományos bábaság egyes elemei a XX. század második felének gyakorlatában?

A korabeli tankönyvek és orvostörténeti források alapján elmondható, hogy az oktatásbeli szemléletváltások apránként jelentkeztek és minden bizonnyal lassan mentek végbe, amihez hozzájárulhatott a bábák és a szülő nők hagyományokhoz való ragaszkodása, valamint az intézményi struktúra rugalmatlansága. Az individuális és a különböző intézmények szemléletmódbeli különbségei rámutatnak, hogy a XX. század közepén a szülészeti kultúra nagyfokú diverzitása figyelhető meg, nem pedig a technokrata orvoslás monolitikus uralma.

\section{Bábaasszonyok Somogyból}

A nagyatádi helytörténeti kiadványok figyelmes forgatásával rátalálhatunk a XIX.-XX. század néhány helybéli bábájára. ${ }^{8} \mathrm{~A}$ Bősze Sándor szerkesztette kétkötetes monográfia információi szerint 1885-ben három bába dolgozott Nagyatádon. ${ }^{9}$ A községi szülésznő Steiner Rozália Budapesten szerzett oklevelet 1874ben. A magyar mellett németül is beszélt, fizetése hatvan forint volt. A községben két magánszülésznő is dolgozott: Selmeczi Sándorné, aki ugyancsak Budapesten szerzett oklevelet, valamint Fekete Józsefné, aki a pozsonyi bábaképzőben diplomázott. Ők a magyaron kívül más nyelvet nem beszéltek, fizetésükröl hivatalos adat nincs.

A XX. század első felének elismert nagyatádi szülésznője volt Valcsics Vendelné Szani Terézia (18741950). Férje korai halála után a budapesti Magyar Királyi Bábaképző Intézetben tanult és szerzett oklevelet, majd visszatér szülőföldjére és 1908-tól képesített községi szülésznőként dolgozott. A 35 . jubileuma alkalmából az Intézet díszérmével tüntette ki. Az 1950-ben megnyílt szülőotthonból ment nyugdíjba és ugyanezen évben hunyt el. ${ }^{10}$ Rajtuk kívül egy taranyi bába Ritupel Franciska neve maradt fenn a helyiek emlékezetében, aki Fáni néniként volt ismert. ${ }^{11}$

8 Somogy vármegye első ismert bábája Eva Kollerin Pesten szerzett oklevelet 1788 végén. Krász 2003. 200. 6. sz. táblázat

9 Bősze (szerk.) 2001b. 87. Az SML fszb. 1900/1885. alapján

10 Györe (szerk.) é.n.

11 Dr. Mohay Andás gyerekorvos NVM-ben tárolt emlékirataiban szeretettel emlékezik meg Fáni néniröl. A pontos nevére nem emlékezett, az információt a „Nagyatád retro” nevü Facebook csoportban kaptam, melynek szerepére a szülöotthon kapcsán még visszatérek.

\section{Két balatonberényi példa a század első feléből (1907-1952)}

A Magyar Nemzeti Levéltár Somogy Megyei Levéltárának dokumentumai között két bába iratait örzik. Mindketten a XX. század első felében tevékenykedtek - a pécsi bábaképző elvégzése után Balatonberényben, ${ }^{12}$ feltehetően egymást követve. Ugyan a Balaton mellett fekvő település társadalmi összetétele számottevő eltéréseket mutat a dél-somogyi községekhez képest, rövid forráselemzést végzek a kutatási távlatok érzékeltetése céljából.

Brávácz Józsefné Dobos Katalin 1878-ban született Karádon. ${ }^{13}$ A pécsi Magyar Királyi Állami Bábaképezde nyári tanfolyamát végezte el 1907-ben, az oklevelén Doktor Sándor - az egyetem emblematikus orvosának - aláírása szerepel. Novembertől már Balatonberény községben dolgozott bábaként, amiröl a Születési napló (1907-1931)14 tanúskodik. Ebben összesen 699 szülésről található feljegyzés. Ez az egyetlen olyan általam vizsgált dokumentum, amely - ha érthető módon hiányosan is - egy világháború minden évéből tartalmaz feljegyzéseket születésekröl. Sajnos a napló táblázatának kitöltési hiányosságai, a tinta esetleges elmosódásai néhol használhatatlanná teszik az adattöredékeket. Ennek folytatása a Szülések jegyzőkönyve (19311938), ${ }^{15}$ melyben 187 szülésről készült dokumentáció. Bráváczné több mint 30 éves pályafutása során 886 általa regisztrált szülésnél vett részt.

Az első világháború előtti időszakban átlagosan évi 40 szülés történt Brávácz Józsefné jelenlétében. A háború alatt ez a szám felére csökken, ${ }^{16}$ majd az 1920-as évektöl körülbelül 25 és 30 közöttire tehető. Amíg a század első évtizedeiben nem volt ritkaság, ha egy nő a nyolcadik, tizedik, sőt két esetben a tizenharmadik gyerekét szülte meg, az 1930-as években ez már nem volt általánosnak mondható. Ebben az időszakban megszaporodnak a bábanapló vetélésről szóló bejegyzései: összesen 21 terhesség ért véget vetéléssel. ${ }^{17}$

1933-tól már lehetőség van az abortus arteficialis orvos által történő legális elvégzésére. ${ }^{18}$ Ettől függetlenül mindenhol a spontán vetélés terminus olvasható. Nehéz megmondani, hogy valódi spontaneitásról van-e szó minden esetben. Ha nem, milyen születésszabályozási módszer állhat a háttérben és van-e köze

12 Ebben az időszakban nagyjából 1400 fös település.

13 Az SML XIV. 55. számú fond tartalmazza az oklevelét és két bábanaplóját.

14 Sujánszky nyomda, Keszthely

15 Mérei nyomda, Keszthely

16 Itt nyilvánvalóan több faktor is közrejátszik a születések számának csökkenésében. A bábanapló folyamatos vezetésére utal, hogy minden évből találunk benne adatokat, még ha hiányosan vagy alig kitöltve is, tehát jó okunk van feltételezni, hogy a drasztikus csökkenés nem a bábai figyelmetlenség vagy hanyagság terméke.

$172,27 \%$

18 Németh 1992. 81. Figyelembe kell vennünk azt a körülményt is hogy a bábák által alkalmazott népi abortív technikák nem estek a hivatalos szabályozás jogkörébe. Másrészt számolnunk kell a közösségek belső rendjének sajátosságaival. Lehetséges, hogy a megtürt bába általi - akár spontán, akár szándékosan előidézett - vetélés kevésbé volt hatással a nő további életére, mint egy kórházban történő (legális) abortusz. 
a bába személyéhez? Valódi jelentős vetéléstöbbletről beszélhetünk, vagy csupán a hivatalos adminisztrációban történt változást? Ezekre a kérdésekre a rendelkezésemre álló adatok nem adnak kielégítő választ, azonban néhány hasznos információval szolgálnak.

Általánosan két vagy három hónapos terhességek megszakadásáról szól a dokumentáció. Egy öt hónapos „halott, maczerált magzat” spontán vetéléséről szóló jegyzetben orvosi aláirás is szerepel, ami jelenlétére illetve közremüködésére is utalhat. Egy másik esetben a vetélés „orvos jelenléte nélkül folyt le”. Öt bejegyzésben szerepel az „ab. imp.” terminus ${ }^{19}$ társítva az „ujjal befejezett” megjegyzéssel. A (spontán) vetélést követően, ha a méh tartalma nem ürül ki teljesen, szövődményekhez vezethet (vérzés, fertőzés és láz) veszélyeztetve ezzel a nő életét, így bizonytalan helyzetben szükséges lehet a méh - jelen esetben kézzel történő - mesterséges kiürítése. Egy ilyen eset után az orvosi megjegyzés rovatban a következő szöveget olvashatjuk: „Műszerei régiek, az előírtak kicserélve most sincsenek. 1933.” Egy évvel később: „Műszerei régiek.” Hogy e körülmények mennyiben befolyásolták Bráváczné munkáját, arról nincsen kielégítő információm. Azonban tudható, hogy az újszülöttek halálozási száma nem emelkedett, csupán a vetélések száma.

$A z$ összes feljegyzett szülés közül 29 végződött az újszülött halálával. ${ }^{20} \mathrm{Ha}$ a halálozás a szülést megelőzően vagy aközben, még az anyaméhben ált be a halva született megjegyzés olvasható a naplóban. Több esetben fennálló kockázati tényező a magzat farfekvése, láb- és homloktartása vagy az elöl fekvő lepény. Egy feljegyzés szól a bába közvetlen beavatkozásáról, ${ }^{21}$ három esetben orvos általi műtétről. ${ }^{22}$ Egyetlen 1928-as esetnél fordult elő, hogy magas láz fellépése miatt az anya és az újszülött sem élték túl a szülést. Mint látható, a bábaasszony munkásságának bőven van tehát feltáratlan aspektusa, csupán nagy vonalakban igyekeztem felvázolni a későbbiek során hasznosnak ígérkező információkat.

Az őt követő bába, Riba Mária 1889-ben született Orda községben. A pécsi Magyar Királyi Erzsébet Tudományegyetem bábatanfolyamát 1930-ban végezte el, oklevelén Scipiades Elemér orvostanár aláírása szerepel. Munkáját 1939-ben kezdte meg, legalábbis erre enged következtetni a Szülések jegyzőkönyve (1939-1941) ${ }^{23}$ és a tény, hogy Brávácz Józsefné előző év végén hagy fel bábai teendőivel. A Bábanaplóval (1947-1952) ${ }^{24}$ együtt összesen 184 általa feljegyzett szülésről van tudomásunk, melyeknél bábaként vett részt. A két napló között kimaradó évekböl, második világháború alatti tevékenységéröl nincs információnk, így munkásságának mindössze kilenc évéröl maradt fenn dokumentum.

19 abortus imperfectus $=$ befejezetlen, tökéletlen vetélés

$203,27 \%$

21 „Húzást gyakoroltam, szülésznő."

22 "Műtétet végeztek a keszthelyi és a szentgyörgyi orvosok.; Műtétet végezte Lanbergel doktor úr.; Mütétet Fülöp doktor végezte."

23 Kiadó: Hangos Géza, Budapest (Ugyanaz a nyomtatvány, mint amit Boli Irma használt ebben az időszakban.)

24 Fenyvesi nyomda, Kaposvár
Az első naplót kinyitva, rögtön a belső borítón gyerekfirkákba botlunk. Rajznak nem nevezhető, bizonytalan kéz húzta kisebb-nagyobb vonalak keresztezik az üres oldalt. Egy feltehetően felnőtt kéz pedig a „Csibím” szót írta a hátsó fedőlap tetejére, ahol hasonló firkálmányok találhatók. Ebböl arra lehet következtetni, hogy Riba Máriának volt saját gyereke és ő készíthette a „rajzokat” édesanyjának. Az egyébként nem túl feltűnő vonalkák egészen személyes jelleget kölcsönöznek a munkaköri kötelességböl szorgalmasan vezetett füzetnek, így a benne szereplőket kevésbé hajlamos a kutató puszta statisztikai adatként kezelni, igyekszik megtalálni a sorok közt az embereket.

A naplók leginkább említésre méltó adatainak ezúttal a férjek foglalkozásai bizonyultak. Ahogy arról már szó esett, egészen más társadalmi csoportok képviseltetik magukat a Balaton déli partján, mind a jóval archaikusabb - föként földművesek lakta - Dél-Somogyban. A különböző mesteremberek (hentes, szíjgyártó, bognár, cipész, asztalos, pék), uradalmi alkalmazottak (kocsis, juhász, cseléd, kanász) mellett a vasútvonal közelsége miatt számottevő MÁV alkalmazott is szerepel a foglalkozások listáján. Olyan ritkaságokat is olvashatunk, mint fodrász, csendőr törzsőrmester, hangyaszövetkezeti alkalmazott, budapesti kereskedő vagy párttitkár. Természetesen itt is akad bőven az alsóbb társadalmi rétegből származó földműves, segédmunkás és famunkás cigány, de képviselteti magát a helyi értelmiség is: állami iskolák tanítói, igazgatói és orvosok. A szocialista rendszerre jellemző foglalkozások is megjelennek: tanácselnök, tenyészállat-ellenőr, gyári munkás, szövetkezeti terménybegyűjtő. A nők foglalkozásáról - már ha volt nekik egyáltalán, négy-öt gyerek mellett - nem tudunk meg semmit.

Figyelemre méltó a bábai feljegyzések precizitása a szülés körülményeire vonatkozóan. Az esetlegesen fellépő komplikációkat rendszeresen feltünteti az arra szolgáló rovatban. Az élet és halál közötti mezsgyén egyensúlyozva a mérleg nyelve hol erre, hol arra billen. Szerencsétlen esetben egy duplán nyakra tekeredett köldökzsinór megpecsételi az újszülött sorsát. Riba Mária feljegyzései szerint az összes szülésből 17 esetben halt meg az újszülött közvetlenül vagy pár nappal a szülés után ${ }^{25}$ és 6 terhesség végződött vetéléssel. ${ }^{26}$

A halál okai között szerepel az újszülöttkori anoxia (oxigénhiányos állapot) két esete: az ún. kék álhalál (livid asphyxia), melyről abban az esetben beszélhetünk, ha a születést követően az újszülött légzése elégtelen (nem lélegzik, nem sír fel), viszont a szívműködése kielégítő, míg fehér álhalál (algid asphyxia) esetében légzési és keringési zavarról van szó. Három esetben a bába fel tudta éleszteni a csecsemőt, szintén háromszor esett meg, hogy nem sikerült. ${ }^{27}$ Két ikerszülésböl egy alkalommal egyik magzat sem ma-

$259,23 \%$, utóbbi 2 esetben fordult elő.

$263,26 \%$

27 „1939.IX.23. Kék álhalál, koraszülött. Odaérkezésemkor már halott volt.; 1940.II.23. Fehér álhalál, beteg volt, meghalt 24-én. Orvosi bejegyzés: elhúzódó, gyenge szülési fájások.; 1940.X.14. Fehér álhalálba született, nem sikerült feléleszteni." 
radt életben, ${ }^{28}$ másszor egy méhen belül elhalt magzat ${ }^{29}$ mellöl került ki szerencsésen egy kisfiú. Tudomásunk van viszont első szülő nő koraszülött ikreiről, akik mindketten az egészséges megjegyzést kapták. ${ }^{30}$

A szülő nőkre vonatkozó információink között is akadnak említésre méltó kivételek. Egy harmincöt éves, háztartásbeliként hivatkozott özvegy első gyerekét szülte meg 1948-ban, aki a bába megjegyzése szerint „törvénytelen”. Azonban tudva levő, hogy az 1946. évi XXIX. tc. a házasságon kívül született gyermek jogállásáról eltörli a törvénytelen státuszt, vagyis a megjegyzés íródásának idejében jog szerint már nem létezett különbség házasságon belül vagy azon kívül született gyerek között. Lehetséges, hogy a bába nem tudott a törvényröl és ezért jegyzett fel nem létező státuszt, de az is elképzelhetö, hogy nem jogilag, hanem a közösségi normák szerint ítélt. A gyakorlatban ugyanis sokkal tovább tart az ilyen stigmák feloldása, lassabban változik a közösség belső rendje (már ha változik), mint a hatályos törvények.

Egy másik özvegy 1950-ben lezajlott, negyedik szülése mellett szerepel még a házasságon kívüli megjegyzés, azonban a lánycsecsemő ismeretlen okok miatt meghalt. Az információk szegényességéből fakadóan nem szolgálhatunk egyértelmű magyarázattal, már csak azért sem, mert több hajadon nő szülésénél is részt vett Riba Mária (még a törvénytelen státusz eltörlése előtti időszakban is), de egyiknél sem szerepelt hasonló megjegyzés.

Két gátrepedést dokumentáló bejegyzésen kívül nem található a frissen szült nő állapotára, esetleges sérüléseire és kezelésükre való utalás. Arra vonatkozó adatot sem találunk a naplókban, hogy az esetleges orvosi beavatkozások hol és milyen körülmények között történtek.

A vetélések vizsgálatánál figyelembe kell vennünk, hogy 1933 és 1952 között lehetőség volt a terhesség legális művi megszakítására. ${ }^{31} \mathrm{~A}$ Riba Mária által regisztrált vetélések közül csupán egy esetben olvashatunk 2 hónapos terhesség megszakadásáról. A fennmaradó öt terhesség, mind jóval később, az ötödik hónap környékén végződött vetéléssel. ${ }^{32} \mathrm{Az}$ abortusz szó csupán egyszer, 1952 márciusában szerepel a Bábanaplóban egy huszonöt éves nő harmadik terhessége kapcsán.

A fent említett két bábaasszony munkásságának teljes körü elemzésére jelen tanulmányban nem vállalkozhattam. Rövid ismertetésük kettős célt szolgált: egyrészt szerettem volna rávilágítani a feltáratlan anyag meglétére és értékes mivoltára, ami egyben jelzi a kutatási téma távlatait, térben és időben való kitágí-

28 Koraszülött, éretlen magzatok. Orvosi bejegyzés: „Túl sok magzatvíz miatt szakadt meg a terhesség. (polihydramnion)

29 Összesen három macerált magzatról olvashatunk a naplókban.

30 Éjjeli szülés következtében az ikerpár tagjainak születésnapja különböző napokra esik

31 Németh 1992. 81. 1945 és 1952 között tisztiorvosi engedéllyel már ingyenesen vehető igénybe az egészségügyi szolgáltatás, melyet a második világháború utáni tömeges katonai nemi erőszak tett indokolttá.

32 1941: 16cm-es fiú magzat; 1949: macerált, felismerhetetlen nemü; 1950: 5 hós fiú; 1951: 5 hós lány; 1952: felismerhetetlen nemü. tásának lehetőségeit. Másrészt bizonyítékot szolgáltat a megyén belüli jelentős társadalmi különbségek meglétére. A továbbiakban áttérek az általam részletesen vizsgált dél-somogyi bábák életének és munkájának bemutatására.

\section{Egy körzeti bába feljegyzései Belső-Somogyból: Horváth Gyuláné Boli Irma naplói (1935-1953)}

Kutatómunkám egyik legfontosabb állomása a Nagyatádi Városi Múzeum volt, ahol 2017 nyarán végeztem az egyetemi szakmai gyakorlatom. Itt őrzik Horváth Gyuláné Boli Irma rinyaújlaki bábaasszony hagyatékát. A továbbiakban - főként a tárgyi és szöveges emlékekre hagyatkozva - bemutatom a bába életének általam ismert mozzanatait, pályája alakulását. A tárgyi hagyaték szemlézése után, a fennmaradt bábanaplók és szülési feljegyzések segítségével megkísérlem rekonstruálni a korra jellemző lokális demográfiai tendenciákat és szülési gyakorlatot.

Boli Irma 1908. augusztus 8-án született Rinyaújlakon (Somogy vármegye) Péti Katalin és Boli István lányaként. A család gazdálkodásból tartotta fenn magát saját birtokán. Első férje Bencze Imre, akitől egy fia született. ${ }^{33}$ 1935-ben végezte el a Magyar Királyi Erzsébet Tudományegyetem bábaképzőjét Pécsett, majd visszatért a községbe és okleveles bábaként dolgozott Rinyaújlakon, ${ }^{34}$ ahonnét az első általa kísért szülési feljegyzés is származik. ${ }^{35} \mathrm{~A}$ harmincas évek végén elvált férjétől és újraházasodott Horváth Gyulával, ${ }^{36}$ akit Pécsen ismert meg. Egy lányuk született 1942-ben, Horváth Irma. (1. ábra)

A Szülések jegyzőkönyvében található feljegyzések 1937-ben abbamaradnak és csak tíz évvel később, 1947-ben folytatódnak. Valószínűsíthető, hogy a férj munkája miatti sürüsödő költözések okán szünetelt a naplóírás. ${ }^{37}$ Horváth Gyula a második világháborút megelőzően lépett munkába a csendőrségnél mint rádiós, távíró. A háború alatti áthelyezéseket követően tértek csak vissza Rinyaújlakra. Boli Irma ugyanezen évben lépett munkába községi szülésznőként. ${ }^{38}$ Értékes kordokumentumnak számít az ekkor kézhez kapott OTI igazolványa. ${ }^{39}$ Bár egyetemet végzett bábaként és immár községi alkalmazottként saját jogán dolgozott és rendelkezett önálló keresettel, a tagsági igazolványon egyedül leánykori neve szerepel. Minden más adat a

33 ifj. Bencze Imre. A csurgói Mezőgazdasági Technikumban végezte tanulmányait, majd 1954-ben Sopronban bányaolajmérnöki képesítést szerezett és Ajkán kezdett el dolgozni. Később visszatért Somogyba, jó kapcsolatot ápolt féltestvérével. Svégel Jánosné szíves közlése. Saját gyűjtés 2017

34 Az 1934-1935-ös év végzős bábanövendékeinek tablója a múzeum tulajdona. Készítette: Kozma Márton, Pécs.

35 Szülések jegyzőkönyve 1935-1950. Kiadó: Hangos Géza; Budapest, Kálvin tér 5 .

36 Született: 1903.12.30., Balatonszentgyörgy. A második világháború előtt a csendőrségen, utána a kaposvári SÁÉV-nál dolgozott vasbetonszerelöként, ahol sztahanovista élmunkás volt.

37 Hogy bábatevékenységet folytatott-e vagy sem, arról nincs értékelhető dokumentumunk.

38 A belépés bejelentését igazoló szelvény. 1947.04.01.

39 Országos Társadalombiztosító Intézet Tagsági igazolvány 


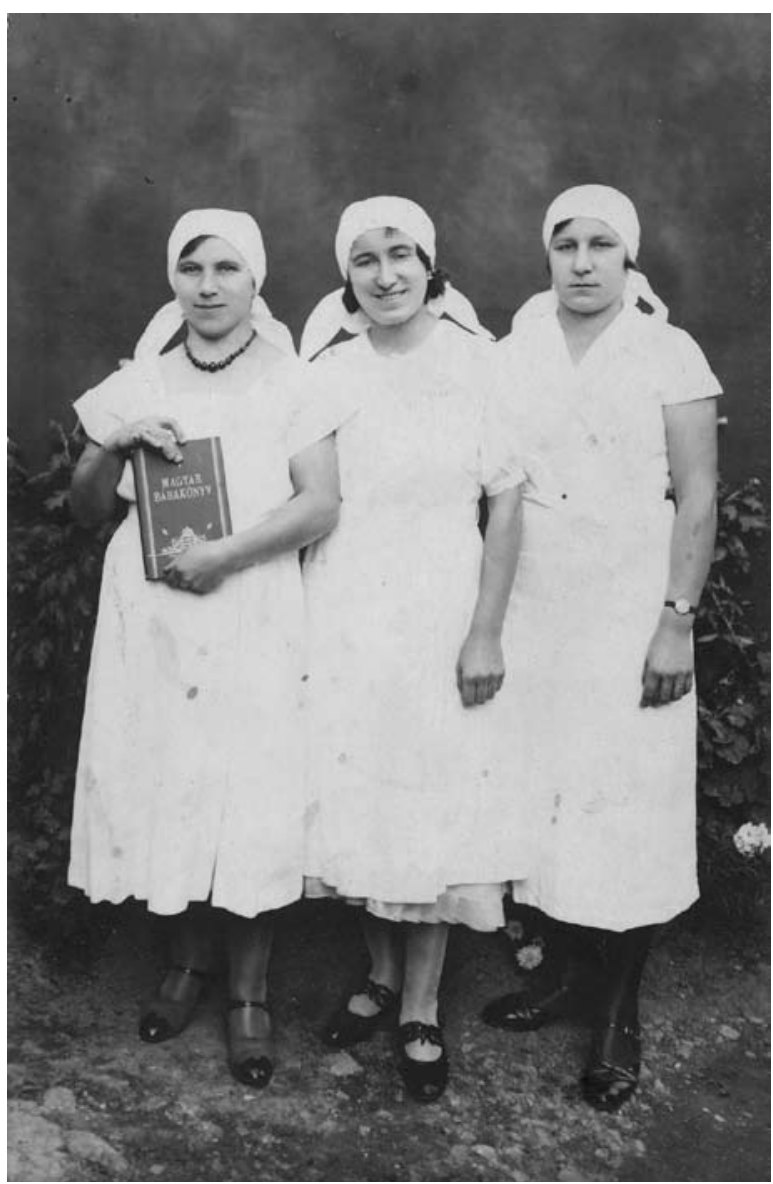

1. ábra. Pécsi bábanövendékek az 1930-as évek derekán, középen Boli Irma.

A fotó a Nagyatádi Városi Múzeum tulajdona

férjé, ${ }^{40}$ erőteljesen jelezve ezzel a szimbolikus gesztussal az erőviszonyok valódi mivoltát. A 210.353/1947. VIII. N. M. sz. rendelet értelmében egy hónapos továbbképzésen kellett részt vennie a Kaposvári Vármegyei Közkórházban, amelyet kielégítő eredménnyel zárt. „Megtanulta az anya és csecsemővédelem érdekében létesült állami rendelkezéseket."

A hagyaték tartalmaz egy különnyomatot a magzatelhajtásról, melyet a Magyar Orvosok Szabad Szakszervezetének Makói csoportja jegyez..11 A Nemzeti Bizottság 1945-ös döntése értelmében engedélyezték és ingyenessé tették az abortuszt, amely gyakorlaton csak a 81/34/1952. egészségügyi minisztériumi utasítás változtat. ${ }^{42}$ Mivel nyomtatott évszám nem szerepek a kiadványon nem állíthatom teljes bizonyossággal, de

40 Még a születési dátum és az anyja neve is. Az anyós nevének szerepeltetésével tulajdonképpen kiragadják vér szerinti családjából és immár a férfi rokonságához tartozónak számít hivatalosan. Annyiban meglepő ez a feudális szokásjoghoz visszanyúló adminisztrációs lépés, hogy alig egy évvel később az 1948. évi XLIII. tc. kimondja a nők és férfiak teljes egyenjogúságát.

41 Somogy vármegye Csokonyavisontai kör orvosának pecsétje és egy kézzel írott 1947-es évszám szerepe rajta, valamint a bába neve, tehát közvetlenül neki utalhatták ki a füzetet.

42 Pető 2005. 303-304. feltehetően ellentétes szellemiséget képviselt a feltételezett keletkezés idején hatályos jogszabályokkal.

Hivatalos dokumentumok igazolják, hogy Boli Irma 1950-ben tbc szürésen vett részt, melynek eredménye negatív. 1951-ben kezdi el írni a Bábanaplót, melyben két év feljegyzései szerepelnek Rinyaújlak, majd 1953ban Istvándi községből. ${ }^{43} \mathrm{~A}$ Boli szülöket a rinyaújlaki 30 holdas birtokuk miatt az ötvenes évek elején kulákká minősítették, melynek következtében földjüket elveszítették. ${ }^{44}$ Röviddel ezután az édesapa, Boli István elhunyt, az anyát a falusi tanácstitkár részegen kidobta a házból, így kénytelen volt Istvándiba menni a lányához. Boli Irma ezután kérelmezte áthelyezését a barcsi szülőotthonba, arra hivatkozva, hogy Istvándiban kevés a szülés és mivel a legtöbb szülés már kórházban zajlik, munkája hasznosabb lenne Barcson. A szülök családi házát 1954-ben kapták vissza. Boli Irma Istvándiból, majd Rinyaújlakról járt be a barcsi szülőotthonba dolgozni. Szeretett kézimunkázni, kertészkedni. Hímzett falvédőiből néhány darab megtalálható a múzeum textilgyűjteményében. 1974-ben hunyt el hosszú betegség után Nagyatádon. A régi, rinyaújlaki házat elbontották, ma már csak a nagy gazdasági épület áll eredeti állapotában. A telken hasonló stílusban építettek új házat, mellette ma a helyi iskola konyhája müködik. ${ }^{45}$

A bábai hagyaték rendszerezése során több szempontból is csoportosíthatjuk a tárgyakat. A múzeumban kialakult rendszer a tárgyak eredeti elhelyezkedését veszi figyelembe és így alakultak ki a praktikum elvén szerveződő tárgycsoportok: az orvosi táska és tartalma, az eszköztartó zsák és tartalma, a textilek és a szöveges dokumentumok. Utóbbival most nem, csak a későbbiekben foglalkozom, a bábanaplók adatainak feldolgozása során. Így maradt tehát három, jól elkülöníthető tárgycsoportunk. Mivel a múzeumban alkalmazott, leltári szempontokon alapuló rendszer néhány ponton zavart keltene az elemzés során, így kísérletet teszek a tárgyak újracsoportosítására.

Legkézenfekvőbbnek a funkcionalitást alapul vevő rendszer bizonyul, amellyel szintén három kategóriára osztom a tárgyakat: a bába ruházata, a szülés alatt használt eszközök ${ }^{46}$ és a szülés lefolyásához konkrétan nem kapcsolódó tárgyak.

$\mathrm{Az}$ első csoportba kerülnek azok a textilek, amelyeket a bába munkája során magán viselhetett: fehér ujjatlan köpeny, fejkendö, textilkesztyü, szájkendő, viaszosvászon kötény és vöröskeresztes karszalag. A második csoportba kerültek: fakanál, gumikesztyü, üveg és fém katéterek, gumicső, üvegcső, érfogó, magfogó, neomagnol tablettákat tartalmazó üvegcse, olló, köldökcsipesz, szemcseppentő és gézlapok. A harmadik csoport tárgyai: orvosi táska, eszköztartó zsák, körömke-

43 Magyar állami nyomda, Budapest 1947

44 A kuláklisták összeírásának kötelezettségéről, illetve az 19501953 között lezajlott kampány környékbeli vonatkozásairól lásd: Bősze (szerk.) 2001. 261.; Országos vonatkozásban lásd: Valuch 2005. 188-193. továbbá Závada Pál: Kulákprés. 1986.

45 A kiegészítő életrajzi adatokhoz segítséget nyújtott: Hauptman Gyöngyi és Svégel Jánosné. Saját gyűjtés 2017.

46 Az újszülött és a frissen szült nő ellátására szolgáló eszközöket is ebbe a kategóriába sorolom. 
fék, gyógyszeres doboz, fém tartály, gyógyszeres üveg, használati utasítás, törlőkendő, damasztkendő, vászonkendő. A ruházathoz különösebb magyarázatot nem füznék, csupán annyi adalék információval szolgálnék, hogy a köpeny elején saját kezüleg hímzett monogram található, ami hangsúlyozza a ruhadarab személyességét. ${ }^{47}$

Magyarázatot igényel azonban a szülés alatt és után használt eszközök csoportja. A fakanalat akkor használták, ha a szülés során epilepsziás roham lépett fel: ilyen esetben gézbe csavarva tették a fogak közé. A hagyatékban lévő tárgy újszerü állapota arra utal, hogy nem sokszor lehetett szüksége rá a bábának. ${ }^{48}$ Az üvegcső - a bábakönyvekben foglalt információk szerint - a beöntések elvégzéséhez volt szükséges. A fog nélküli érfogó, más néven pean az apróbb erek elszorításához használt ívelt végü, ollóhoz hasonló eszköz. A magfogó ennél hosszabb, egyenes végű eszköz, amelyet tamponok és kötszerek eltávolítására használtak. A korban használt modern fertőtlenítőszer a neomagnol a korábban használatos, ám erősen mérgező szublimátot $\left(\mathrm{HgCl}_{2}\right)$ váltotta fel. ${ }^{49} \mathrm{~A}$ köldökzsinór elvágása előtt az újszülött köldökcsonkjára fém csipeszt helyeztek, hogy megakadályozzák a vérzést. A vágást tompa végü ollóval végezték, mely géz szabására is alkalmas volt. A szemcseppentő szintén az újszülött ellátása végett került a táskába: a szem kitisztítására használták az esetleges látásproblémák megelőzése okán.

A harmadik funkcionális csoportba soroltam azokat a textileket, melyek nem tartoztak a bábaasszony ruházatához. Ezek használatáról konkrét információ nem áll rendelkezésemre, de az anyagok állapotából arra lehet következtetni, hogy nem a szülés közben használták a testnedvek letörlésére. Valószínüsíthető, hogy ezekre a textilekre helyezték ki vagy ezekkel törölték el fertőtlenítés után a fém eszközöket. A körömkefe egyértelmüen a kezek - bábák számára különösen fontos - tisztaságát szolgálta. Ide soroltam még a tárolóeszközöket és a különféle gyógyszeres üvegcséket, valamint ezek tokjait.

A használati tárgyak rendszerezése után áttérek a szöveges dokumentumok - azon belül is föképp a bábanaplók - részletes elemzésére. Boli Irma bábaságának kilenc éve rejtőzik a Szülések jegyzőkönyve és a Bábanapló lapjai közt, mely idő alatt 159 szülésnél volt jelen. ${ }^{50} \mathrm{~A}$ precízen, szép kézírással vezetett naplók és a kifogástalan állapotban lévő tárgyak is arra engednek következtetni, hogy tulajdonosuk odaadással fordult szakmája felé.

Adataink vannak a szülés idejéröl, a szülő nö51 életkoráról, lakhelyéről, eddigi szülései számáról, a férj foglalkozásáról, a magzat fekvéséről és neméről (esetlegesen a keresztnevéről) valamint fennálló

47 A tárgyak emlékezetéről lásd: Assmann 1999. 20.

48 Ezt a feltételezést támasztja alá, hogy egy feljegyzésben sem szerepel epilepsziára vonatkozó utalás.

49 A Népjóléti Minisztérium 3134/N/2/1949.XI./1. sz. rendelete a bábatáska kötelező elemeként határozza meg a szert.

50 Ehhez hozzátartozik egy 1935. októberi bejegyzés, viszont ezt nem számítottam külön évnek, hiszen csupán egyetlen szülésröl van szó.

$51 \mathrm{Az}$ esetek többségében a férjezett és a leánykori név is szerepel a feljegyzésekben. betegségröl, bekövetkezett halálról vagy vetélésről. Évente átlagosan 17 szülés történt a bába körzetében. A legtöbb 1948-ban, a legkevesebb 1937-ben. (2. ábra) A szülő nők életkora szempontjából legnépesebb csoportot a 21 és 25 év közöttiek alkotják. Legfiatalabb 16, a legidősebb 42 éves. Lakhely szerint a kimagasló többség Rinyaújlakon élt. Több szülés történt még csokonyavisontai, gézapusztai ${ }^{52}$ és istvándi lakosoknál. A legtöbb nő első gyerekét szülte a bábával. A legmagasabb szülésszám egy tizenegyedik gyerekével terhes, 35 éves cigány nőnél figyelhető meg. A férjek foglalkozásából tudjuk, hogy a szülések fele földmüvesek családjában történt. ${ }^{53} \mathrm{~A}$ magzat fekvése legtöbb esetben első koponyatartású, legkevésbé jellemző az arctartás. Az újszülöttek nemi aránya $4 \%$-os többletet mutat a fiúk javára. Összesen hat halálesetröl van tudomásunk: négy magzati halál és két szülést követő elhalálozás. Vetélésről három feljegyzés tanúskodik. A továbbiakban a fenti kategóriák mentén elemzem a bábanaplók tartalmát, rávilágítok az információk összefüggéseire és az ezek alapján felmerülő kérdésekre.

\section{Szülések száma 1935-1937; 1947-1953}

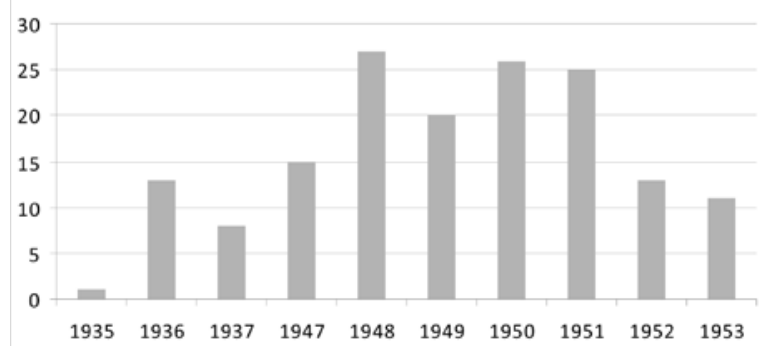

2. ábra. Szülések száma évenkénti bontásban. Boli Irma feljegyzései alapján

Életkori megoszlás szempontjából hat csoportra osztottam a szülő nőket, ötévenkénti határmeghúzással. ${ }^{54}$ A legfiatalabbak első, ritkábban második gyereküket szülték a bábaasszonnyal. A húsz éven felülieknél már nagyobb változatosságot lehet kimutatni: általánosan első-harmadik gyereküket szülik, nem feltétlenül egyenes arányosságot mutatva az életkorral. Akad 21 évesen harmadszorra, 23 évesen ötödszörre terhes nő is. A huszonöt éven felettiek jellemzően második-negyedik gyereküket szülik, de tudunk olyan esetekröl, mikor a nők 26, 27, sőt 30 évesen szülik meg első gyereküket. ${ }^{55}$ A harminc éven felüliek jellemzően negyedik-hetedik szülésüknél fordultak a helyi bábához. Kiugró adatnak

52 Ma Rinyaújlak része.

53 Itt megjegyzendő, hogy a két napló eltéréséből fakadóan nem lehet százalékos arányt kimutatni az összes szülésre vonatkozóan. A Szülések jegyzőkönyvében feltüntetett a férj foglalkozása, viszont a Bábanaplóban már nem. További eltérés, hogy a Bábanaplóban jegyzett a nő vallása, a Szülések jegyzőkönyvében viszont nem, így e tekintetben csupán részinformációink maradtak fenn.

5420 év alattiak, 21-25 év közöttiek, 26-30 év közöttiek, 31-35 év közöttiek, 36-40 év közöttiek, 40 felettiek.

55 Utóbbi kiugró adat 1948-ból származik, egy vendéglős családból. 
számít a 35 évesen tizenegyedik gyerekét szülő cigányasszony. A harmincöt éven felüliek ötödik-hetedik szülésükhöz, a negyven éven felüliek a nyolcadikhoz hívták a bábát. Egy 42 éves háztartásbeli nő tizedik szüléséről is van információnk.

A lakhely szerinti megoszlásnál a legnépesebb csoport értelemszerüen Rinyaújlak és a szomszédos Csokonyavisonta községben élt. Egy-egy adatunk van olyan környékbeli helységekböl, amelyek mára beolvadtak a településekbe: Lajosmajor, Alsócser, Felsőcser, Terézmajor, Köblöspuszta. A szintén betagozódott Gézapusztáról jelentős mennyiségű szülési feljegyzésünk van. Somogyaracs és Nagydobsza ma is önálló községek. A major, cser és puszta elnevezések utalnak a vidék jellegére: ezek a nők mind földművesek, napszámosok és uradalmi cselédek feleségei voltak.

$A z$ itt élők társadalmi helyzetére vonatkozóan a férjek foglalkozásai adnak támpontokat. A Szülések jegyzőkönyvének adatai szerint az összes szülés felénél az apa földmüves vagy napszámos, tehát paraszti származású volt. Mivel a Bábanaplóban nincsenek feltüntetve a foglalkozások, csak feltételezhetjük, de az $50 \%$-os arány valószínüleg tovább növekedne. Ebbe a kategóriába sorolhatjuk még az uradalmi cselédeket és pásztorokat. Szintén a paraszttársadalom tagjai a mesteremberek: kovács, faragó, szűcs. Fizikai munkásként jelen van a tejcsarnokkezelő és a gyári munkás. Állami alkalmazottak, vasutasok, szövetkezeti könyvelő és vendéglős is szerepel a bejegyzésekben. A helyi értelmiség is megjelenik: a református és az állami tanító gyerekét is Boli Irma segítette a világra.

A vallási megoszlásról érdemben nem tudunk szólni, mivel csak a szülések töredékénél jegyeztetett fel a felekezeti hovatartozás. Ebböl azonban kiderül, hogy mind katolikus, mind református nőkhöz járt a bába; két és félszeres katolikus többséggel. A dolog érdekessége, hogy csak az 1951-1953 között szült nőknél jelenik meg a vallásra vonatkozó adat, amikor a politika igyekezett háttérbe szorítani az egyházakat.

A térségben jelen lévő etnikai csoportok közül egyedül a cigánysággal találkozunk a bábanaplók hasábjain. Összesen kilenc cigány nő szült a vizsgált időszakban a bábával. ${ }^{56}$ Egy kivétellel mind a leánykori nevükön szerepelnek a dokumentumokban. Ennek hátterében valószínűsíthetően a cigány közösségek normarendszere áll, miszerint a házasság intézménye nem a hivatalos polgári szertartáshoz kötött, hanem a közösségen belül megtörtént ceremóniához. Így fordulhat elő, hogy cigány házaspárok úgy élik le az életüket, hogy a köztük lévő köteléket csak a közösség ismeri el, ám hivatalos papírok híján az állam nem tekinti őket házasnak. A regisztrált szüléseknél egy kivétellel lánycsecsemők születtek. Előfordult fiatal cigány nők első vagy második, idősebbek negyedik szülése is.

56 Ez nem feltétlenül jelenti, hogy csak ennyi gyerek született, könynyen lehet, hogy nem minden cigány nő fordult bábához, vagy másik bábával szültek.
A legtöbbet szült nő is a cigányok közül került ki: egy harmincöt éves nö ${ }^{57}$ szülte meg tizenegyedik gyerekét 1948-ban. A bejegyzés érdekessége, hogy a bába nem használt a szülés során szublimát lepényt. ${ }^{58} \mathrm{Ez}$ a körülmény és az eddigi szülések nagy száma arra enged következtetni, hogy ha nem is a bába segítsége nélkül (az ilyen esetek jelölve vannak a naplóban), de viszonylag önállóan szülhette meg a nő lánycsecsemőjét. A szublimát használatának hiánya egy másik cigány nő59 1950-ben történt szülésénél is olvasható. Feltűnő, hogy egyazon napon két szülés történt a napló szerint, ám a bába időrend szerint felcserélte a sorszámozást. Elsőként szerepel, hogy a késő délelőtti órákban szülte meg első gyerekét egy helyi állami tanító felesége. ${ }^{60}$ A második bejegyzést kora délelőttre datálták, bő egy órával korábbra. Az ebben említett fiatal cigány nő második gyerekét szülte. Mivel itt nem szerepel helyszín, nem tudjuk biztosan, de kétséges, hogy a bába egyszerre két szülésnél vett volna részt. A szublimát használatának hiánya is azt a gyanút erősíti, hogy a cigány nő szülése a bába különösebb segítsége nélkül zajlott le.

Említésre méltó még az a ceruzával írt és utólag kiradírozott bejegyzés, ahol a fiatal cigány nőnél a hajadon státusz szerepelt. Már utaltam a cigány közösségen belüli házasodási viszonyok bonyolult mivoltára, de a bábanaplókban ez az egyetlen, ahol a nő egyedülállósága hangsúlyt kap. Az 1950-ben második gyerekét szülő nő adatainak részleges eltüntetésére nincs magyarázatunk, ugyanis a törvénytelen gyerek státusza ebben az időszakban már nem létező jogállás. Az újszülöttre vonatkozó adatok szerint élveszülés történt, még egy keresztnév is olvasható, tehát sem magzatsem gyerekgyilkosságra sincs okunk gyanakodni.

A magzatok fekvését illetően az első koponyatartásban születettek jelentik a legnépesebb - több mint a szülések felét alkotó - csoportot. Szintén számottevő a második koponyatartásban született magzatok száma. A far- és arctartás, valamint a medencevégü fekvés összesen nyolc esetben fordult elő. Ezen utolsó csoportból három esetben halva született a magzat, két esetben pedig pár óra után veszítette életét, vagyis látható, hogy a magzat fekvése meghatározó jelleggel bírt a szülés végkimenetelét illetően.

Az újszülöttek nemek szerinti megoszlása a fiúk javára mutat kevés többletet. A feljegyzett adatok szerint 72 lány és 79 fiú született Boli Irma bábáskodása alatt. Keresztnevek közül népszerü az Erzsébet, Mária, László és István. Egy 1900-as nagyatádi adat szerint akkoriban a Julianna, Anna, János és Lajos voltak a legnépszerübb nevek. ${ }^{61}$

58 A szublimát $\left(\mathrm{HgCl}_{2}\right)$ fertőtlenítésre használt, vízben oldódó vegyület. A szülés során elhasznált szublimát lepények száma utal a fertőtlenítő oldat mennyiségére, vagyis ha nem használt szublimátot, nem történt fertőtlenítés.

59 O. M

60 P. E.

61 Bősze (szerk.) 2001b. 482. Női nevek közül dobogós volt még a Mária, melynek népszerüsége úgy tünik csak növekedett. 
A halálozások tekintetében három halvaszületésröl, két születés utáni és egy koraszülés következtében történt elhalálozásról számolhatunk be. 1948-ban egy huszonhat éves nő62 ötödik szülése olyan rohamos gyorsasággal következett be, hogy a bába nem ért oda időben. A problémát a magzat farfekvése és a szaksegítség hiányának együttese okozhatta, melynek következtében halva született a fiú magzat. ${ }^{63}$ Egy két évvel későbbi esetben egy huszonhét éves nő ${ }^{4}$ harmadik terhessége végződött a magzat halálával. A medencevégű fekvésben lévő halva született magzatnál szerepel egyedi esetként a macerált kifejezés. ${ }^{65}$

A vetélések kapcsán egy nő két esetéről kell szót ejtenünk. H. E. első feljegyzett vetélése 1947-ből származik. Az akkor harminc éves földműves-feleség negyedik terhessége szakadt meg. A körzeti orvosi bejegyzés nehezen olvasható, de annyi bizonyos, hogy a „kivérzett nő" terminust használja, ${ }^{66}$ valamint elvégezte a méhüreg ujjal történő kiürítését. H. E. második vetélésére 1951-ben került sor, az akkori hatodik terhességével. ${ }^{67} \mathrm{Ez}$ a feljegyzés a Bábanapló leghátuljában szerepel. Boli Irma Istvándiból kerül a barcsi szülöotthonba 1954. január elsejével. Az utolsó szüléshez 1953. december hatodikán ment ki házhoz. ${ }^{68} \mathrm{Ez}$ a Bábanapló 38. oldalán szerepel, majd bármiféle köztes tartalom nélkül a 96 . oldalon áll erről a vetélésröl szóló bejegyzés. A kérdésre, hogy miért írhatta ide a bába a vetélést, nem tudunk egyértelmü magyarázattal szolgálni. Ugyan orvosi megjegyzés nem szerepel az oldalon, de az igen, hogy a vetélés után húsz perccel megérkezett a helyszínre az orvos. Azt is tudjuk, hogy másnap történt szülés a községben, ami a napló kronologikus rendjében jó helyen szerepel, tehát nem állíthatjuk, hogy véletlen hanyagság áll a háttérben. Egy harmadik vetélés is történt a bábaasszony munkássága során: 1950-ben egy huszonegy éves nő második terhessége szakadt meg a korai szakaszban. ${ }^{69}$

Orvosi közreműködésre több okból is sor kerülhetett. Hat alkalommal a gátrepedés összevarrása, három esetben a szülés levezetése végett volt rá szükség. Tizenhárom egyéb alkalommal található orvosi aláírás a naplókban. Két szülés folyt le mindennemü szaksegítség nélkül, három végződött kórházba szállítással. Összesen egyszer fordult elö, hogy az anya szülés után belázasodott. 1950-ben egy fiatal nő első szülése utáni harmadik napon érkezett ki hozzá az orvos. A hüvely- és gátrepedéshez a bába nem hívott

62 S. K.

63 Körzeti orvosi megjegyzés tárgyalja a körülményeket.

64 A. I. Figyelemre méltó, hogy a nő és férje családneve megegyezik. Hasonlóval máshol nem találkoztam.

65 A macerált magzatokról a bábakönyvekben lásd: Reismann 1932. 164.; Szathmáry 1948. 275

66 Ez a megfogalmazás áll legtöbb helyen a terhes nő vagy a bába által megindított vetélés kapcsán, melynek befejezését a súlyos vérzés következtében orvos végzi el.

67 Az ötödik terhességéből származó gyereket is Boli Irma segítségével szülte meg, vagyis nemcsak a vetélései kapcsán fordult hozzá

68 A napló hivatalos lezárása nem történt meg.

69 Ez a Szülések jegyzőkönyvének hátsó borítóján szerepel - a többi év végi szüléssel együtt -, így egyéb információnk nincs is ezzel kapcsolatban. Azon kivételes esetek egyike, amikor csak a férjezett név szerepel a füzetben. orvost, így azok összevarrására csak napokkal később került sor, miután a méhüregböl - feltehetően visszamaradt - lepénydarabokat távolított el, melyek a lázas állapotot okozták. ${ }^{70}$ Nem derül ki a bejegyzésből, hogy a bába észlelte az eredeti problémát vagy csak a lázra lett figyelmes. Azonban abból az információból, hogy a bábának napokkal később is tudomása volt a gyerekágyas nők aktuális állapotáról és abból a körülményből, hogy havonta átlagosan egy-két szülésnél volt jelen arra következtethetünk, hogy még életben volt a hagyományos bábaság gyerekágyas időszakra is kiterjedő gondoskodói és segítői gyakorlata.

Végezetül azon nőkröl kell szólnunk, akik több alkalommal is igénybe vették a bábaasszony segítségét. Nyolc nőröl tudunk, aki legalább kétszer, háromról, aki legalább háromszor és kettőről, aki négyszer szült Boli Irmával. A fiatalon sokat szülö nő példája K. R., aki 1948-ban, húsz évesen szülte meg második gyerekét, majd huszonhárom éves koráig összesen négy gyereket szült. A kilencgyerekes P. M. egyike volt a legelső Boli Irmával szülő nőknek. 1936-ban, huszonhét évesen szülte meg a második gyerekét, egy évre rá a harmadikat. A következő adatunk 1949-ből származik, mikor negyven évesen megszülte a nyolcadik, majd egy évre rá a kilencedik gyerekét. Hogy a köztes időszakban kinél szült arra vonatkozóan nincs információnk.

Horváth Gyuláné Boli Irma munkásságának feltárása hozzásegíthet minket a korszakról alkotott ismereteink kiszélesítéséhez és a bábamesterség vizsgálatának továbbgondolására is alkalmas lehet, minthogy a lokális, mikrotörténeti kutatások képesek hozzájárulni a történelmi folyamatok kritikai reflexiójához. Az okleveles bába munkásságában megfigyelhető a modern elvárásoknak megfelelő szakszerüség és a - feltehetően - hagyományos elemeket is tartalmazó gyakorlatok keveredése. Az ötvenes évek elején saját maga kérelmezte a szülőotthonba való áthelyezését, ami egyszerre utalhat a hatékonyabb munkavégzés iránti vágyára, valamint az intézményi struktúrába való belépés elkerülhetetlenségének felismerésére, de akár anyagi szempontú döntés is állhatott a háttérben. Boli Irma életének bemutatása révén - a cseppben a tenger elvet szem előtt tartva - reményeim szerint közelebb kerülhetünk a XX. század bábaságának feltérképezéséhez.

\section{Dudás Béláné Horváth Mária nagyatádi szülésznő életútja (1953-1987)}

Boli Irma bábai dokumentumai segítségével 1953ig - a barcsi szülőotthonba való áthelyeztetéséig - kísérhetjük végig pályájának alakulását. Ebben az évben kezdi meg munkáját Horváth Mária, a dolgozatom által bemutatni kívánt másik somogyi bába. A szülésznővel készült interjúk és a nagylelküen rendelkezésemre bocsátott korabeli feljegyzései segítségével a nagyatádi szülöotthon és a kórház történetének egy szeletét kívánom felvázolni, helytörténeti források felhaszná-

70 Nem tudni mi okozta a bába figyelmetlenségét, de a zavart csak tetézi, hogy a gyerek adatainál gond nélkül szerepel egymás mellett a leány és a László megjegyzés. 
lásával. Elsőként az iskolai tananyag és az interjúk alapján próbálom meg rekonstruálni a Horváth Mária által képviselt szemléletmódot, valamint az esetleges eltéréseket az oktatásban tanultak és gyakorlati alkalmazásuk között. A két intézmény (szülőotthon, kórház) rövid történetét tematikus fejezetekben tárgyalom, itt csak azon eseményekre térek ki, melyek szorosan kapcsolódnak a szülésznő pályájához. ${ }^{71}$ Ezen kívül foglalkozom még az interjúk során említett „szokatlan” szüléstörténetekkel és röviden kitérek a cigányság és az egészségügy kapcsolatára is.

Horváth Mária 1927-ben született egy erdőcsokonyai ${ }^{72}$ háromgyerekes cseléd família középső gyerekeként. 1951-1953 között végezte tanulmányait Szegeden, a Martos Flóra Állami Szülésznőképzőben, ${ }^{73}$ ahol okleveles szülésznői képesítést szerzett. Az ott tanulók társadalmi-gazdasági hátteréről sokat elárul, ${ }^{74}$ hogy interjúalanyom elmondása szerint az igazgatónő tanította meg késsel-villával enni a lányokat, mert nem tudták, hogyan kell. A beszélgetés során szívesen emlékezett vissza a szegedi évekre, iskolai jegyzetfüzetét megőrizte. Kéthónapos szülésznői gyakorlatát Budapesten végezte 1953 márciusától májusig. ${ }^{75}$ Ebben az időszakban negyven szülésnél vett részt, melyről egy Szabad Népbe csomagolt ún. észlelési füzet tanúskodik. Ezután került vissza szülöföldjére, Somogy megyébe. A harmincnégy éves pályafutása során a nagyatádi szülőotthonban, majd az 1976-ban megnyílt kórházban dolgozott a nyolcvanas évek végéig.

A szegedi előadásokról ${ }^{76}$ feljegyzett ismeretek alapján képet kaphatunk az adott intézet oktatásban uralkodó szemlélete felöl. A kezdeti alapvető információk (menstruáció, peteérés stb.) után a szülő nőhöz intézendő kérdések listája, ${ }^{77}$ majd a házi szülés feltételei jelennek meg a füzetben. A rendes és rendellenes szülés ismérvei mellett anatómiai ismeretekröl és a

71 Megjegyzendő, hogy elbeszélése során végig szülésznőként hivatkozik magára és pályatársaira is, ezért ebben a fejezetben kontextus függvényében - ezt a megnevezést használom. Mivel jelen tanulmányban nem tárgyalom a bába és szülésznő szavak etimológiáját, ezért közel azonos jelentésben használom őket. A címben és a szöveg nagy részében a bába szó használata mellett döntöttem, utalva ezzel a mesterség kontinuitására és az általa implikált szemléletmód képviseletére. A bába szó kapcsán lásd: Deáky 1996. 31-34.

72 Ma Csokonyavisonta

73 1948-ban az akkori nevén Kossuth Zsuzsanna Állami Ápolóképző Intézetben megkezdődött a két éves bábaképző megszervezése. Egy évvel később népi kollégiummá alakult és felvette Martos Flóra nevét. Az igazgató akkoriban Molnár IIma egészségügyi védönő volt. http://www.kossuthzs-szeged.sulinet.hu/bemutatkozunk/ az-iskola-tortenete/kzs [Utolsó elérés: 2018.07.26.]

74 Egy későbbi, 1965-ös apróhirdetés-rovatban megtalálható az iskola felhívása fiatal lányok számára, ami a bábaképzőbe való jelentkezésre buzdít. Feltétel a nyolc általános elvégzése volt. Petőfi Népe 1965.02.17. 20. évf. 40. szám

75 A tanulmány megírása utána került birtokomba egy másik füzet, amely ugyanerről az időszakról tartalmaz szülési feljegyzéseket. Az ebben szereplő adatok szerint a szülésznő 1953 augusztusáig kísért szüléseket - szám szerint 82-t -a budapesti klinikán. Az új információk elemzése és az eredmények továbbgondolás egy későbbi tanulmány részei lehetnek.

76 Elöadó: Dr. Kovács István, a csecsemőgondozásról Dr. Halmágyiné (utóbbival külön nem foglalkozom).

77 A vallásra vonatkozó kérdés „hibás, fasiszta korból származik”. Ugyanezen időszakban Boli Irma jegyzi a vallási hovatartozást. szülés szakaszainak időtartamáról is találunk leírást. ${ }^{78}$ A szülésznő táskájának tartalmát is meghatározták a törvényi előírásoknak megfelelően. A leírásban nem csak a tárgyak felsorolása szerepel, hanem utalásokat találunk a funkciójukra is, például a nemi szőrzet megrövidítésére alkalmas olló vagy borotva, hüvelyöblítés és beöntés céljára külön üvegcső. ${ }^{79}$ Újdonságnak számított a gumilepedő és a nyákszívó. A szülés szakaszainak tárgyalását az előkészítéssel kezdi, melynek során megkövetelt eljárás a szeméremszőrzet eltávolítása, a beöntés elvégzése.

A szőrzet eltávolítását többféleképpen értelmezhetjük. A beavatkozás mellett szóló fő érv a higiéniai szempontokra hivatkozik. A rituális értelemben tisztátalannak számító szülő nő képe ismert a kulturális antropológiai ${ }^{80}$ és a néprajzi szakirodalomban. ${ }^{81}$ Itt azonban nem a nő mint személy, hanem kizárólag a nemi szerv és környéke jelenik meg „tisztátalanként”. ${ }^{82}$ A deperszonalizáció a szülés technológiai modelljéhez kapcsolható, ahol a szőrzet mint bakteriális veszélyforrás jelenik meg. A hiedelmeket elvető és a tudományosságra támaszkodó modern orvostudományról alkotott képet azonban cáfolják a bizonyítékokon alapuló orvoslás kutatási eredményei, miszerint nem mutatható ki különbség a fertőzések tekintetében a szőrzet eltávolítása kapcsán. ${ }^{83} \mathrm{Az}$ Egészségügyi Világszervezet legfrissebb ajánlásában a rutin borotválás elvetendő gyakorlatként szerepel. ${ }^{84}$

A (női) test egy adott társadalmi normarendszerbe ágyazódva jeleníti meg annak legitim kódrendszerét. Ezek koronként és kultúránként változnak, de látnunk kell, hogy a szőrzet viselése vagy nem viselése soha nem az egyéni preferenciák vagy az „esztétikum” mentén alakulnak, hanem politikai töltettel is bírnak. ${ }^{85} \mathrm{~A}$ szörzet hiányának kulturális értelmezése szerint a csupasz nemi szervek a gyermeki állapotot idézik ${ }^{86}$ és - a nemi szőrzet szexualitáshoz való erős kapcsolódása okán a nem nélküliséget is implikálhatják. ${ }^{87} \mathrm{Az}$ ortneri természetet képviselő nő csak úgy léphet át a kultúra - férfiak

78 „Ha a szülés bármely időszaka eltér az átlagostól, az mind valamely szövődmény jele."

79 A tananyag megerősíti azt a korábbi feltételezésemet, miszerint a bábahagyatékban található textilek a műszerek sterilitásáért feleltek (erre helyezték rá). Magyarázatot ad az érfogó (pean/kocher) használatára is: a köldökzsinórt szorították el vele.

80 Douglas 2001.

81 Bővebben lásd: Bárth 2007., Csonka-Takács 1999., Juhász (szerk.) 2009. A menstruáció kapcsán: Deáky 2005

82 A tabuk kapcsán megjegyzendő, hogy a tiltás és elkülönítés mellett mindig ott van a szentség is. A tabu alatt álló személyek természetfelettivel való kapcsolatából ered speciális státuszuk, vagyis nem puszta lefokozásról van szó, hanem egy szó szerinti másállapotról, ami eltér a hétköznapok normalitásától. Frazer 1998. 140-145.

83 „The present review found no evidence of any clinical benefit with perineal shaving." Basevi - Lavender 2014. 2.

84 WHO 2018. 68. Az előző, 1985-ös ajánlásban is ugyanez szerepelt. Az ajánlás alapjául szolgáló kutatási eredményeke lásd: http://apps.who.int/iris/bitstream/10665/186383/1/WHO_ RHR 15.21 eng.pdf [Utolsó elérés: 2018.07.26.]

85 A női testszőrzet kulturális vonatkozásainak részletes elemzését lásd: K. Horváth 2016.

86 Davis-Floyd 1987. 484

87 Greer 2002. 34-35. Shiela Kitzinger értelmezésében a nőiségtől való szimbolikus megfosztottságként jelenik meg és párhuzamot von a katonák vagy rabok hajának leborotválásával. Kitzinger 2005. 
által uralt - birodalmába, ha levetkőzi a természettel és civilizálatlansággal azonosított szőrzetét. ${ }^{8}$ A szülő nő rutinszerü borotválása, - melynek pozitív hatásait láthatóan semmilyen tudományos bizonyíték nem támasztja alá - a rituális cselekvésekkel mutat kapcsolatot.

A folytatásban a szülésznő kitolási szakaszban való teendőiröl olvashatunk a tananyagban. A szülő nő hanyatt fekvő pozícióját tekintik evidensnek, amely szemléletmóddal már a korábbi bábatankönyvekben is találkoztunk. Horváth Mária elmondása szerint ez a „professzor és az orvostanhallgatók kényelmét” szolgálta. ${ }^{89} \mathrm{~A}$ kitolás alatti gátvédelem alkalmazása kapcsán meg kell jegyezzük, hogy bár a bábaképző tananyaga részletesen tárgyalja fontosságát, az interjúk során a szülésznő túlnyomórészt az episiotomia (gátmetszés) alkalmazásáról beszélt. Utóbbira akkor került sor, ha „a hüvelybemenet szűknek bizonyul”. Az általam vizsgált tankönyvekben is hasonló vélekedéseket olvashatunk, vagyis az orvos/szülésznő szubjektív megítélésére van bízva a beavatkozás elvégzése ${ }^{90}$. A gátrepedések típusai és kezelésük ismertetése is szerepel a tananyagban. Az interjú során a szülésznő többször, gondosan elismételte a helyes varrástechnikát, amit horgos tüvel, belülröl kifelé haladó öltésekkel végeznek.

Horváth Mária a has lepedővel történő „lekötéséről” is beszélt, ami segített „lejjebb húzni a gyereket”. Elmondása szerint a magzati szívhangot eszköz nélkül, a fülükkel hallgatták a szülésznők, akik azt is meg tudták állapítani pusztán a hang alapján, hogy farfekvéses-e a magzat. A tananyagban olvasható az újszülöttek ellátásának lépései. Először a nyák eltávolítása, majd a szemcseppentés és a köldökellátás következett. A köldökzsinór elvágása csak a pulzálás megszünése után ajánlott. A jegyzetben szereplő „magzati vér” és „lehúzzuk a vért a magzat testébe" kifejezések arra engednek következtetni, hogy itt még nem azzal a szemlélettel találkozunk, miszerint a „köldökzsinór vér” nem tartozik szervesen a magzathoz. Azonban az interjú során a kórházi szüléseknél megjegyzi Horváth Mária, hogy „hamar elvágták” a köldökzsinórt. A vetélések kapcsán csak a missed ab. (visszatartott vetélés) kerül szóba. Ilyenkor a szülésznő „sohase próbálja maga bevégezni, hívjon orvost", mert a vetélés előidézése nem megengedett.

A bábaképzésen a szülészet történetét is oktatták a korszak elvárásaihoz igazodva. A tudományág fejlődésére és annak gátló tényezőire helyezi a hangsúlyt a narráció. Utóbbi kategóriába sorolja a babonaságot, a boncolásra vonatkozó tiltásokat, az egyházat, illetőleg azt, hogy a daraboló műtéteket végző sebészorvosoknak „fogalmuk sem volt a normális szülészröl”. Említésre kerül „Szemelveis” Ignácz Fülöp, „Taufer”

88 Paradoxonnal tünhet, hogy a szőrtelenítéssel felidézett gyermeki állapot ugyancsak a természethez kötődik szorosabban, mégis ezáltal integrálható a nő a kultúra szférájába. A gyermekiség egyben a döntésképtelenség és a kiszolgáltatottság állapota, vagyis a nö részese lehet a kultúrának, de csak bizonyos korlátozásokkal. Vö.: Ortner 2003. 206.

89 Dudás Béláné Horváth Mária szóbeli közlése. Saját gyűjtés, Nagyatád, 2017.

90 Szathmáry 1948. 308. és 311.
Vilmos, a gyermekágyi láz és a kórokozók szerepe is. A Horváth Mária által rendelkezésemre bocsátott másik kéziratos forrás az ún. észlelési füzet, amely a bábanaplóhoz hasonlóan a szülő nő adatait és a szülés lefolyásának dokumentációját tartalmazza. Az eddig vizsgált bábanaplókhoz képest eltérés, hogy nem csupán a szülés végkifejlete feljegyzett, hanem - a szülésznői gyakorlat jellegéből adódóan - a teljes folyamatról pontos leírást ad. A füzet teljes egészében kézzel írt, nem tartalmaz nyomtatott rubrikákat. A feljegyzések tartalmazzák a szülő nő nevét, születési dátumát, esetenként lakcímét, foglalkozását és első menstruációja időpontját, a magzat fekvését, valamint az előző szüléseknél fellépő komplikációkat. Ezután rögzíti a szülőszobára való felvétel percre pontos idejét és óránként beszámol a méhszáj állapotáról, a magzati szívhangról és a fájásokról. Az utolsó megjegyzésben szerepel az újszülött neme és a méhlepény megszületésének ideje.

Összesen negyven szülésröl szóló feljegyzést olvashatunk a füzetben, vagyis átlagosan havi húsz szülésnél volt jelen a frissen végzett szülésznő. ${ }^{91} \mathrm{~Eb}-$ ben az időszakban anyai vagy magzati halálozás nem fordult elő. A szövegben ismétlődő elem a „szabályos előkészítés után felvéve a szülőszobára” kezdeti frázis, illetve a „normális gátvédelem mellett megszületik az élő, érett fiú/leány magzat”. Az újszülöttek nemi aránya 24-16 a lányok javára. Gátmetszést összesen hat szülésnél végeztek. ${ }^{92}$ A méhlepény megszületésére vonatkozó feljegyzésekben egy kivétellel (ahol 15 perc olvasható) minden esetben 10 perc után történik a placenta leválása, ami valószínűtlennek tünik. Gyanítható, hogy az egységes megfogalmazás inkább formaság, mintsem a valós adatok tükre.

A szülő nőkre vonatkozó adatokból kiderül, hogy foglalkozás szempontjából jelentős csoportot alkotnak a háztartásbeliek ${ }^{93}$ és a munkásnők. ${ }^{94}$ Előfordult még tisztviselő, könyvelö, takarító és könyvkötő is. A vajúdás részletes dokumentációjából kiderül, hogy a legrövidebb vajúdás ideje egy, míg a leghosszabbé tizenkét óra. ${ }^{95} \mathrm{~A}$ feljegyzésekből megállapítható, hogy nem mutatkozik összefüggés az eddigi szülések száma és a vajúdás ideje között, vagyis jelen minta alapján nem tünik megalapozottnak az a mítosz, hogy a sokszor szült nők könnyebben szülnének. ${ }^{96}$

91 Ebböl első terhesség: $20 \mathrm{db}$, második: $8 \mathrm{db}$, harmadik: $6 \mathrm{db}$, ötödik: $4 \mathrm{db}$, hatodik: $1 \mathrm{db}$, tizedik: $1 \mathrm{db}$.

92 Dr. Roth és Dr. Pataki.

93 Tizenöt nő.

94 Tizenöt nő, köztük vegyesen: segédmunkás, gyári munkás, betanított munkás, gépmunkás, csiszolómunkás, szerelömunkás, magkészítő

95 A legtöbb nő átlagosan három-négy órát vajúdott

96 A leghosszabb, tizenkét órás vajúdás egy hatodszorra szülő nőnél figyelhető meg. Az ötödik gyereküket szülők vajúdási ideje kettő és öt óra közé tehetök. Az elöször szülő nők körében nagy változatosság mutatkozik kettőtől tíz óráig. Mivel a forrás jellegéből adódóan nincs adatunk ugyanazon nő szüléseiröl, így egyéni alkatra vonatkozó megállapításokat nem tehetünk. 


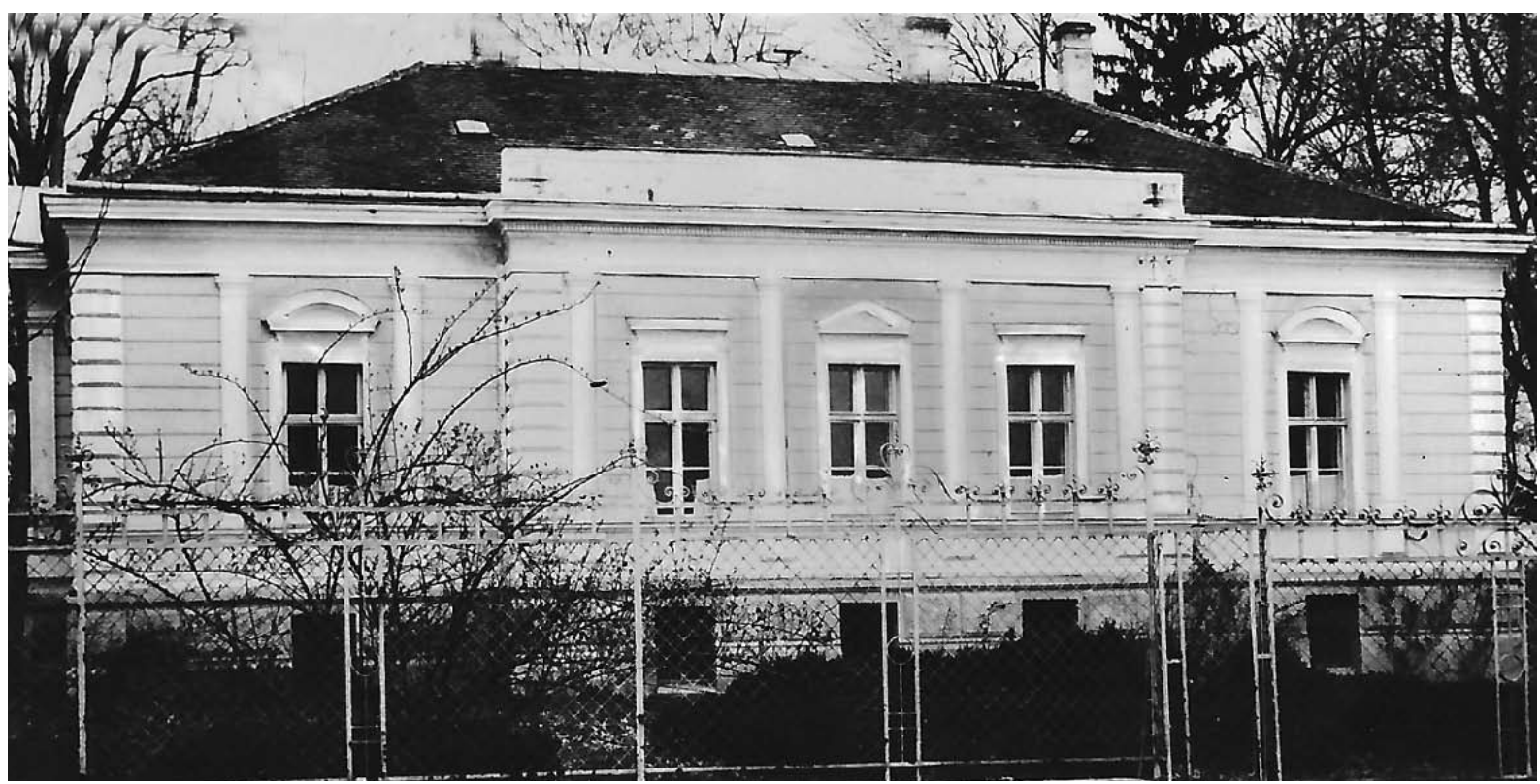

3. ábra. Nagyatádi szülőotthon. Eredeti képeslap Steiner Józsefné gyüjteményéből (elveszett), reprint változat a Nagyatádi Városi Múzeum tulajdona

\section{A nagyatádi szülőotthon emlékezete (1950-1976)}

A tanulóévek után Horváth Mária visszatért Nagyatádra, ahol a helyi szülőotthonban állt munkába az ötvenes évek közepén. A továbbiakban az intézmény rövid történetét mutatom be helytörténeti források és a szülésznő elbeszélése, valamint egy helyi gyerekorvos visszaemlékezése alapján. Itt ejtek szót továbbá a cigány nők és az egészségügyi ellátás viszonyáról is.

Nagyatád a XVIII. századtól a Czindery-család birtokát képezte. Az első ispotály építésére Czindery Donát felesége, Adamovics Erzsébet a végrendeletében adományozott 6000 forintot a községnek. ${ }^{97} \mathrm{Az} 1860$-ig a Szent Ferenciek kolostorában müködő intézmény inkább egyfajta szeretetotthonként, semmint kórházként müködött, ugyanis orvosok nem dolgoztak benne, a betegek csak élelmezést kaptak. ${ }^{98}$ Megszűnése után, 1895-ben Éhn Sándor járási főszolgabíró létrehozott egy pénzalapot a jövendőbeli kórház számára. ${ }^{99}$ Az építkezés megkezdése ugyan közel nyolcvan évet váratott magára, a Nemzeti Bizottság 1945. szeptemberi ülésén felvetődött a kórház létesítése iránti igény. A simongáti Mándy-kastély mérete alapján megfelelő lehetett volna a célra, azonban túlságosan rossz állapotban lévőnek ítélte meg a bizottság, így a várható magas költségek okán elálltak a tervtől. Azonban a Népjóléti és Egészségügyi Főhatóság egy járási szülőotthon megnyitását tervezte, melyhez helyi szövetségesre találtak Hormay Mihály doktorban, akit a helyiek máig a szülőotthon alapítójaként ismernek. ${ }^{100}$

97 Bősze (szerk.) 2001a. 150. SML Jkv. 1794. 219-221.

98 Csorba 1857. 112.

99 Bősze (szerk.) 2001b. 88

100 Dr. Hormay Mihály (1898-1954) az első világháború idején hadiorvos, majd 1945-1950 között tisztiorvos, a szülőotthon alapítója. Györe et al. 2002.
1949 decemberében a közgyülés elfogadta a müködési engedélyt, így 1950. január elsején megnyitotta kapuit a nagyatádi szülőotthon a Lelbach Keresztély által 1896-ban építtetett és a céloknak megfelelően átalakított ${ }^{101}$ neoklasszicista kastélyban. ${ }^{102}$ Ebböl az időszakból három archív fotó maradt fenn, amely az épületet ábrázolja. ${ }^{103}$ (3. ábra) A kastélyt 1976-ban (a kórház átadásának évében) vizesedésre hivatkozva az akkori hatóságok elbontatták. Kovácsoltvas kerítéséből egyetlen elemet sikerült megmenteni az utókor számára, amely eredeti helyén, a jelenlegi Városháza épülete mellett áll. A földesúri kastélyhoz tartozó park öreg vadgesztenyefái máig árnyékot adnak az arra tévedőknek.

A korabeli sajtóban megjelent tudósítások örömmel adtak hírt a szülőotthon létesítéséről, mint az anya- és csecsemővédelmi intézkedések sorába illő modernizációs lépésről. ${ }^{104}$ „Pártunk és kormányunk nagy gondot fordít a dolgozó nők egészségvédelmére, melynek egyik fontos tényezője a szakszerüen levezetett szülés." - írja a Somogyi Néplap. ${ }^{105} 1957$ decemberében egészségügyi kiállítás nyílt a nagyatádi müvelődési házban, külön figyelmet fordítva a „nővédelemre”. „Az egyik sarok-

$101 \mathrm{Az}$ átalakítás költsége 570.000 forint volt a helyi újság beszámolója szerint. A nagyrészt békekölcsönböl finanszírozott beruházás az ötéves terv részeként készült el. Somogyi Néplap 1951.

102 Bősze (szerk.) 2001b. 257. SML jegyzőség 2405/1949. képviselőtestületi jegyzőkönyv.

103 Hauptman Gyöngyi muzeológus elmondása szerint eredetileg képeslapokon szerepeltek a felvételek (Steiner Józsefné gyűjteménye), de már csak reprint formában találhatók meg a városi múzeumban. Ezek közül kettő szerepel a városmonográfiában: Bősze (szerk.) 2001b. 155.; 257.

104 A megyében ekkor öt egészségügyi intézményben lehetett szülni az alábbi városokban: Barcs, Lábod, Lengyeltóti, Marcali, Nagyatád. Nagyatádon bölcsőde és napközi otthon is a dolgozó nők rendelkezésére állt. Somogyi Néplap 1953.

105 1953. (kiemelés tölem: S. F.) 
ban egy szegényes szobaberendezés látható, felette magyarázó szöveg »A felszabadulás előtt a szülések legnagyobb része otthon, egészségtelen körülmények között zajlott le. "Vele szemben a másik sarokban egy korszerü szülőotthon berendezése látható". ${ }^{106} \mathrm{Az}$ ismertetőből megtudhatjuk azt is, hogy a nagyatádi szülöotthon húsz ágyas ${ }^{107}$ és évente körülbelül ötszáz újszülött lát napvilágot az otthonban. ${ }^{108}$ Láthatjuk, hogy a korszak hivatalos narratívájában meghatározó szerepet töltöttek be a fejlődés, a modernizáció és a korszerűsítés hívószavak. A szülészeti viszonyok sablonos és leegyszerüsítő leírása szerint minden elvetendő, ami a régi rendszerrel áll kapcsolatban. ${ }^{109}$

A szülöotthon orvosai közül legismertebb talán Dr. Bacsa Antal sebészorvos, szülész-nőgyógyász. Egy 1958-as újságcikk tudósít a napi munkájáról, miszerint délelőtt vizitel, majd a fonalgyár üzemorvosaként is ellátja teendőit, este pedig az abortuszbizottságok által javasolt terhességmegszakításokat végzi el. ${ }^{110}$ Az orvosi autoritást hirdető narratívát némiképp árnyalja a Horváth Mária elbeszélésében megjelenő szülésznőkép: „Még a sebészorvosra is rászóltam, hogy nem jól csinálja. Mondom neki: »Főorvos úr, ne haragudjon már, de ezt nem így kell csinálni. « Kintről befele varrt, hát úgy szétjön az egész. Mondom, bentről tessék kifele varrni, adja ide, megmutatom. Nekünk így tanították. Ilyen kampós tủvel varrtak... Azt mondja: „Mária, igaza van, de egy sebész már csak így varr.«”111 A szülésznői dominancia több helyen is megjelenik a szülőotthonról szóló elbeszélésében. Visszaemlékezése szerint abban az időben az orvossal szülés nem volt szokványos, külön kérni kellett, egyébként a szülésznők vezették az osztályt. Itt még ők számítottak szaktekintélynek. Egy szülésznő megmondhatta az orvosnak, ha valamit rosszul csinál, mert eltérő képzésben részesültek és a sebészorvosok kevésbé voltak kiképezve a szülészet terén.

Horváth Mária az otthon felszereltségével kapcsolatban úgy emlékszik, hogy a szülőágyak elválasztására nem volt spanyolfal, így felcsíptetett lepedőkkel választották el egymástól a vajúdó nőket. Előfordult, hogy a könnyebb szülés érdekében labdára ültették a nőt, ami „kirázta belőle a gyereket”. Az ágyra gumilepedőt húztak és csak arra terítettek textilt, így kevesebbet kellett mosni. Mária néni megemlékezett a régebb óta ott dolgozó takarítónőkről is, akik besegítettek a szülésznők munkájába; előkészítettek pólyákat, mostak, feltöröltek.

106 Somogyi Néplap 1957. (kiemelés tölem: S. F.)

107 1950-ben négy ággyal nyílt meg az otthon, amit 1951-ben 12 ágyasra, majd egy évvel később 20 ágyasra bővítettek. Laczkó et al. 1971.

108 Vö. A városmonográfia szerint 1900-ban száztíz gyerek született Nagyatádon. Bősze (szerk.) 2001b. 482

109 „A múlt »urai« nem tartották szívügyüknek az anya- és gyermekvédelmet. Ez a felelőtlenség oda vezetett, hogy a gyermekhalandóság ijesztően magas számadatokban mutatkozott meg." Somogyi Néplap 1953. A XIX. század gyermekhalandóság elleni küzdelméröl lásd: Deáky - Krász 2005. 314-323.

110 Somogyi Néplap 1958.

111 Itt Bacsa Antalról volt szó a császármetszések kapcsán. Dudás Béláné Horváth Mária szóbeli közlése. Saját gyüjtés, Nagyatád, 2017.
A szülésznő szívesen és lelkesen mesélt egykori munkájáról. Hangsúlyozta, hogy a szülés előtt gumi katétert vezettek a húgycsőbe, sohasem fémet, mert az megsérthette a burkot vagy a magzatot. A szülőotthonban is alkalmaztak császármetszést, ha szükség volt rá, nem csak a kórházban. Horváth Mária elmondása szerint egy ízben az orvos, úgy belekönyökölt a szülő nő hasába, hogy „szó szerint kiugrott belöle a gyerek, úgy kellett elkapni. Persze a gát szétrepedt, nekem kellett összevarrni."112 Utána meg is mondta az orvosnak, hogy ilyet nem szabad csinálni. Ebben az esetben megfigyelhető a különbség a szülésznői és az orvosi szülésvezetés között. Mária néni - aki visszaemlékezése során végig tisztelettel és szeretettel beszélt a szülő nőkről és az újszülöttekről - szülésről alkotott elképzeléseivel nem volt összeegyeztethető ez a kifejezetten durva, brutális bánásmód. Az orvosi gyakorlat itt további beavatkozások életre hívójaként szerepel, melynek elvégzése a szülésznőre hárult.

E történet kapcsán a szülésznő kifejtette, hogy ha gátmetszésre volt szükség, - a fertőzések elkerülése végett - baloldalon, ferdén vágtak. Érzéstelenítő injekció után elöbb az izom, majd bőr összevarrása következett. A szülésznő szerint ezt könnyebb volt varrni, mint a repedéseket. $A z$ újszülött világra jötte utáni teendőkről is beszélt. A méhlepényből esetlegesen viszszamaradt részekért be kell nyúlni a méhbe kanállal vagy fogóval, majd - a vérzések elkerülése végett - a méhet kiöblíteni. Az orvos onnan tudta, hogy üres a méh, ha az „ropogó” hangot hallatott. A szülésznők a méhszáj állapotát is ellenőrizték, a repedéseket öszszevarrták, majd jódos vízzel lemosták a szeméremtestet és tamponáltak a magfogó segítségével.

A frissen szült nőket minden reggel lemosták, majd ágytálat adtak vérzés esetére. Hasukat masszírozták, hogy könnyebben kijöjjön belöle a vér. A gyerekágyas nőknek megtanították a szoptatást és a fejést. A szülőotthonban szoptatós dajkát is alkalmaztak abban az esetben, ha valakinek nem volt teje. ${ }^{113}$ A lefejt tej közös volt, bármelyik gyerek kaphatta. A visszaemlékezésből látható, hogy a nagyatádi szülőotthonban hasonlóképp jártak el, mint a házhoz kijáró bábák a hagyományos közösségekben. A gyerekágyas időszakra is kiterjedő bábai teendő ${ }^{114}$ továbbélése megfigyelhető a XX. század közepén létesült intézményben.

Horváth Mária elmondása alapján tudható, hogy az újszülött ellátása a köldökzsinór elvágása után vette kezdetét. A köldökcsonkot borsavas vízzel törölték át, majd steril gézlappal fedték és bepólyálták. A szülésznőnek orvost kellett hívnia, aki megvizsgálta a csecsemőt. Kimosták a száját, orrát, bepelenkázták aztán mérlegre tették, hogy lemérjék a súlyát, majd a hosszát és a fej körméretét. Csak ezek után került az anyához.

112 Dudás Béláné Horváth Mária szóbeli közlése. Saját gyüjtés, Nagyatád, 2017.

113 A dajkaság intézményének megszűnését Deáky Zita az 1930-as évekre teszi, de láthatjuk, hogy helyenként még az ötvenes évek után is megfigyelhető a dajka jelenléte. Deáky 2002. 111.

114 Lásd: Deáky 1996. 63. 
„Látod miből lettünk? ... Nem gyerekjáték ám ez. Mindent meg kell tanulni. Azt nem lehet, hogy nem tudja... és ha nincs orvos? Meg kell oldani. Mindent tudni kell."115 - mesélte Mária néni a szülésznői munka felelősségteljes mivoltát hangsúlyozva.

$A z$ intézmény megléte ellenére azonban még sokan szültek otthonukban. Horváth Mária elmondása szerint a szülésznők nem szerettek túlzottan kijárni a házakhoz, mert sokhelyütt rossz körülmények fogadták őket. Gyakori volt - az előre elkészítendő - meleg víz hiánya és nem egyszer későn értesítették a szülésznőt, aki jobb esetben - már csak az újszülött ellátásában segédkezhetett. Szerencsétlen kimenetelű szülés esetén azonban felelősségre vonhatták őket, így biztonságosabbnak ítélték meg a szülőotthoni munkát. A szülésznő az újraélesztés technikáját be is mutatta ottlétemkor: az újszülöttet fejjel lefelé lógatva a hátat kellett a tenyér külső élével simítani, finomat ütögetni, az arcát pacskolni, hogy felsírjon. Elmondása szerint a szülőotthonban föleg szegényebb nők, de iparosok, kereskedők feleségei is szültek. A módosabbak jellemzően inkább bejártak a barcsi vagy a kaposvári kórházba.

Cigányok ${ }^{116}$ a környékből - föleg Mikéből - jártak be szülni Nagyatádra. Az interjú során Horváth Mária mesélt egy történetet, miszerint „egy ilyen fél cigány ember jött be furkósbottal. Nem olyan igazi furkósbottal, de hasonlóval, az övére volt erősítve itt hátul. Attól féltünk, mert jött be a feleségéhez és a szülésznőket meg is fenyegette, hogy ha nem lesz minden jól akkor... mutatott a botjára."117 A kölcsönösen negatív megítélés a szülés mivoltából, a hozzá kapcsolódó félelmekből, az intézmény idegenségéből és a kulturális különbségekből is fakadhat.

Egy másik esetben egy ötvöskónyi cigánylány terhes lett, de nem mondta el senkinek, még az anyjának se. „Azért disznó volt az a lány, legalább az anyjának mondta volna el, akkor az azt mondaná neki, hogy hát lányom itt egy vödör vagy valami... mégse a vécébe szüljön meg."118 A lány kiment a hátsó udvaron lévő vécébe és ott szülte meg a gyereket, aki beleesett az ürülékbe. „Nekem kellett lemosni, olyan büdös volt az a gyerek... meg a kezem is két napig olyan büdös volt... "119 Megmaradt a gyerek, a szülők pedig összeházasodtak. Az nem tisztázott, hogy ebben az esetben véletlenről vagy szándékos „elemésztésről” lett volna szó.

A szülésznő elbeszélése szerint a cigányok házai többnyire sárból tapasztottak voltak, ahol rossz higiénés körülmények között éltek. Volt, hogy lopkodták a lepedőket a szülőotthonból: „Te - mondom az egyik szülésznőnek - itt igen fogynak ezek a lepedők. Aztán rájöttünk, hogy a cigányasszonyok viszik el. Magukra

115 Dudás Béláné Horváth Mária szóbeli közlése. Saját gyűjtés, Nagyatád, 2017.

116 A cigány nök szüléshez való viszonyáról és az egészségügygyel való kapcsolatukról lásd: Erdős 1957., Kalányosné 1999., Neményi 1998.

117 Dudás Béláné Horváth Mária szóbeli közlése. Saját gyűjtés, Nagyatád, 2017

118 Dudás Béláné Horváth Mária szóbeli közlése. Saját gyűjtés, Nagyatád, 2017.

119 Dudás Béláné Horváth Mária szóbeli közlése. Saját gyűjtés, Nagyatád, 2017 csavarják, ráhúzzák a szoknyát, aztán nem vesszük észre. Mert két ajtó volt a szobán, egyik a lepedősbe nyílt, úgy tudták elhozni, hogy nem láttuk." ${ }^{120}$ A szülésznő cigánysággal kapcsolatos emlékeiben megjelenik az egészségügyi személyzet tartózkodó magatartása, a félelem, a romák „érthetetlen” viselkedése és a tolvaj cigány sztereotípiája is. Azonban hozzá kell tennem, hogy Horváth Mária elbeszélése során nem volt megfigyelhető a cigányok negatív színben való feltüntetése. Narrációja inkább semleges, tényközlő volt.

A hagyományos értelemben vett bábai kompetencia példája, hogy Mária néni - elmondása szerint - mindig megérezte, ki mikor fog szülni. Tudta elöre, mikor pihenhet le egy kicsit, mikor kell ránéznie a vajúdó nőre. „Azt mondja az orvos, hogy elmehetek, mert még úgysem lesz itt szülés. Én meg mondtam neki, hogy várjunk még egy kicsit, megnézem én azt a nőt... Hát nem meglett a gyerek még akkor délután? Lehet azt látni rajta, a színéből." ${ }^{121}$ Horváth Mária számára láthatóan fontos a szakmai önazonosság: személyisége elválaszthatatlannak látszik a szülésznői identitásától. A szegény családból származó szülésznő a szakma kitanulása és gyakorlás által vált a közösség megbecsült tagjává. Narrációja és a kiváló állapotban megőrzött tárgyi emlékek is arra utalnak, hogy büszke volt munkájára.

Az interjúk során a szülésznő felidézett néhány számára emlékezetes szüléstörténetet is. Elsőt arra a kérdésemre mesélte el, hogy történt-e haláleset munkája során. Bólogatott és elmondta, hogy egy fiúgyermek születés utáni halálának volt tanúja. Egy szülő nővel foglalkozott, mikor a szomszédos ágyon fekvő nő szülésznőjének lejárt a műszakja és elment. Egy darabig nem jött váltás, így Mária néni egyedül maradt a két nővel, akik egyszerre szültek. Utólag derült ki, hogy a másik szülésznő fém katétert helyezett a nő húgycsövébe, ami miatt megsérült a burokban a magzat. „Mondtam neki utána, hát ezt hogy gondoltad... Ilyet nem szabad csinálni, ez veszélyes. Nekem meg ott volt a saját szülő nőm, hát azzal kellett foglalkoznom."122 Megmenthették volna a babát, ha kap időben egy injekciót, de az emberhiány miatti felfordulásban az orvos azt hitte a szülésznő beadta már, a szülésznő meg azt, hogy az orvos, így aztán a szerencsétlen félreértés következtében meghalt a kisfiú.

Egy hasonlóan tragikus eset kapcsán a szülésznő így emlékezett: „Volt, hogy a Kati ... milyen Kati, jaj nem jut eszembe, na mindegy, szült egy nagy fejü gyereket, aztán elakadt, nem tudták kiszedni. A mentő meg túl későn ért ki." ${ }^{123}$ Egy olyan gyerek is született, akinek koponyáján volt egy csontkinövés. „Az ilyenek nem maradtak meg, nem tudtunk velük mit csinálni.”124

120 Dudás Béláné Horváth Mária szóbeli közlése. Saját gyűjtés, Nagyatád, 2017

121 Dudás Béláné Horváth Mária szóbeli közlése. Saját gyűjtés, Nagyatád, 2017.

122 Dudás Béláné Horváth Mária szóbeli közlése. Saját gyűjtés, Nagyatád, 2017.

123 Dudás Béláné Horváth Mária szóbeli közlése. Saját gyűjtés, Nagyatád, 2017

124 Dudás Béláné Horváth Mária szóbeli közlése. Saját gyűjtés, Nagyatád, 2017 
Egy másik történet szerint Mária néni kiment a lepedőszárogató szobába - oda volt bekötve meleg víz, azért ment - és gyereksírást hallott: „Hát mondom, te jó Isten mi lehet ez, itt nem lehet gyerek, azok máshol vannak, a folyosón messze." ${ }^{125}$ Megtalált egy bepólyált csecsemőt a szennyes lepedők között. Korábban született egy gyerek „kéken” gondolták nem él, mert nem sírt fel és „kirakták”. Abban a szobában hideg volt, nem fütötték. „A hidegben ott feléledt, sírt. Gyorsan bedugtam a meleg víz alá, megfürdettem. Utána elküldtük Kaposvárra. Hát ilyen is volt."126 Korábban már előfordult a kék álhalálból felélesztett újszülött képe az egyik balatonberényi bába, Riba Mária naplójában is.

„Csak azt sajnálom, hogy nem írtam fel hány gyereket segítettem a világra a szülöotthonban. Nem tudom már."127 Horváth Mária idős kora ellenére rendkívül precízen idézte fel a szakmájához kötődő gyakorlatokat, a nagyatádi intézményekben bevett szokásokat és a számára különleges történeteket. Ugyanezen okból kifolyólag pontos számokat vagy helyszíneket nem mindig tudott felidézni. A saját megítélése szerint sikeres szülésznői pályafutásáról szívesen és lendületesen beszélt, ám több konkrétumra nem derült fény a halványodó emlékezete okán.

A szülőotthonban dolgozó orvosokra és egy helyi bábára vonatkozó információt a Nagyatádi Városi Múzeum által őrzött kivételes kordokumentum is szolgáltatott. Dr. Mohay András (1926-2014) ${ }^{128}$ gyermekgyógyász szakorvos levélben küldte el a múzeum számára a Nagyatádon töltött éveiről szóló visszaemlékezését 2000 tavaszán. Az „Egy orvos emlékei.... Nagyatád 1959-1969" címet viselő négyoldalas gépelt szöveg közvetlen stílusban ad számot az orvos mindennapi teendőiről és legemlékezetesebb pillanatairól. ${ }^{129}$

125 Dudás Béláné Horváth Mária szóbeli közlése. Saját gyűjtés, Nagyatád, 2017.

126 Dudás Béláné Horváth Mária szóbeli közlése. Saját gyűjtés, Nagyatád, 2017.

127 Dudás Béláné Horváth Mária szóbeli közlése. Saját gyűjtés, Nagyatád, 2017.

128 Mohay András 1953-ban szerzett orvosi diplomát a Pécsi Orvostudományi Egyetemen. A kaposvári kórházban kezdett el dolgozni, ahonnét 1958-ban kerül Hetes községbe mint körzeti orvos. 1959 októberében került Nagyatádra, Dr. Magyar Vince meghívása által. Körzeti orvosi teendői mellett két órás gyermekszakrendelést és iskolaorvosi tevékenységet is végzett, valamint tagja volt a Mozgó Szakorvosi Szolgálatnak. A szülöotthon újszülött részlegének ellátása és a bölcsődés gyerekek egészségügy felügyelete is hatáskörébe tartozott. A túlterheltség elkerülése érdekében kérvényezésére a hivatalos szervek - az országban másodikként - körzeti gyermekorvossá nevezték ki 1962-ben. Mozgalmas szakmai életéről tanúskodik, hogy folyamatosan járt továbbképzésekre, konferenciákra a Dunántúlon és tagja volt a Szakszervezeti Bizottságnak. A jubileumi kitüntetések mellett a járási tanács elismerő oklevelét is megkapta az anya-, csecsemő- és gyermekvédelem terén végzett kiemelkedő munkájáért. 1969-ben családi okokból került Pécsre, ahol a Központi Nö- és Gyermekvédelmi Intézet csoportvezető gyermekgyógyász főorvosaként dolgozott haláláig. A levelében megadott pécsi címen ma már fia, ifj. Dr. Mohay András dolgozik kardiológusként.

129 A volt betegei is őriznek róla szép emlékeket: „Nagyon féltem az injekciótól, de ő nagyon ügyesen megoldott a problémát. Nyuszit festett rám és azt mondta: látod most a nyuszit kicsit megszúrom, te észre sem veszed. Már nem is féltem. Szerettem őt." H. Gy. A „Nagyatád retro" nevü Facebook csoportban közzétett hozzászólás.
Mohay doktor emlékei szerint az otthonban dolgozott - a már említett egészségügyi szakembereken kívül Dr. Magyar Vince (1921-1996) körzeti- és gyerekorvos. Egy közösségi médiás csoportban fellelt információk szerint néhány idősebb emberben máig élénken él a doktor képe és szívesen gondolnak vissza rá, kiemelve emberségét és segítőkészségét. ${ }^{130} A$ dokumentum említi még Dr. Faragó László szülész főorvos nevét, aki 1961-70 között vezette a nagyatádi szülőotthont.

\section{Kórházi viszonyrendszerek}

Horváth Mária szakmai életére is hatással voltak a nagyatádi egészségügyi ellátórendszer kiépülésének következő lépései. Új egészségház jött létre 1966-ban, melyben gyermekszakrendelés és csecsemő tanácsadó helyiség is üzemelt. 1968-tól öt védőnő látta el a körzeti teendőket a községben, majd 1969-ben megnyílt egy modern hatvanfős bölcsőde. ${ }^{131}$ Somogy megye legfiatalabb kórházát 1976. november 7-én adták át Nagyatádon. A négy évig tartó építkezés befejeződésével az 500 ágyas kórház és rendelőintézet szülészeti osztálya vette át a szülőotthon funkcióját. Utóbbit vizesedésre hivatkozva elbontatta a hatóság ugyanezen évben. Helytörténeti adatok szerint a hetvenes években átlagosan évi kettőszáz szülés történt a városban. ${ }^{132}$

Az egészségügyi személyzet számára az átalakulás nem csak helyszínváltást jelentett, de az intézményi hierarchia módosulását is. Mária néni elmondása szerint - aki a hetvenes évek végén már húsz éves tapasztalattal rendelkező, rangidős szülésznőnek számított - a kórházban a szülésznő adta az orvos kezébe a tálcára kikészített eszközöket, még a tüt is neki kellett elöre befüzni. A szülészeti eszközök használata is jellemzőbb volt: ha az orvos szükségesnek ítélte a has lepedővel való átkötésén túl - még fogóval is benyúltak a méhbe, hogy lejjebb húzzák a magzatot. Egy másik módszer a magzat szülőcsatornából való „kiszívása” a szívófogó segítségével. Elmondása szerint a nehéznek ígérkező szülések esetén az orvosnak időben kellett szólni, nehogy a szülésznőt tegyék felelőssé az esetleges komplikációkért. ${ }^{133}$ Ezen példák némi betekintést nyújtanak a szülésznő által is kiemelt változásba, miszerint a kórházban már egyértelműen a szülészorvosok voltak vezető pozícióban.

A szülés helyszíne tehát olyan szempontból meghatározó jelleggel bírt a szülő nők számára is, hogy a szülésznők által vezetett szülőotthonban még kimu-

130 A „Nagyatád retro” nevü zárt Facebook csoport információi. A csoport a város egykori életének felidézésére jött létre, régi fényképek megosztását teszi lehetővé az érdeklődők számára. A fotók alatt gyakoriak a hozzászólások és a tagok közötti információmegosztások. A szülöotthont ábrázoló képek alatt több ötveneshatvanas években szült nő hozzászólása is olvasható. 2018-ban szerveztek a tagok számára személyes találkozót, tehát alakulóban van egy helyi múltidéző közösség. Megjegyzendő tehát, hogy a csoport alkalmas terepnek ígérkezik digitális etnográfiai kutatások végzésére, esetleges adatközlők felkutatására.

131 Laczkó et al. 1971. Egészséges élet fejezet.; A bölcsődei féröhelyek száma 1981-re 215 före növekszik. Dorcsi - Juhász (szerk.) 1981. 44.

132 Dorcsi - Juhász (szerk.) 1981. 5.

133 Vö: Szathmáry 1948. 311. 
tathatóan érvényesültek a bábai szemléletmód egyes elemei, a kórházban azonban az orvosi autoritás már nem vagy csak kevéssé tette lehetővé a bábai gyakorlatok alkalmazását.

A városi kórházhoz tartozó nővérszállón egészségügyi képzés is folyt, ahol Horváth Mária - szülésznői elfoglaltságai mellett - még kezdő ápolónőknek tanított egészségügyi ismereteket. ${ }^{134}$ Hatalmas munkabírásának bizonyítéka, hogy nyugdíjazása után is visszament dolgozni a kórházba, ${ }^{135}$ mert sokan elmentek az osztályról és szükség volt megbízható szakemberre. Meghívták a 40. jubileumi ünnepségre, küldtek neki kiadványt is, de már nem ment el. Elmondása szerint az utcán nem sokan ismerik meg, de azt tudják a városban, hogy van a Mária néni, aki szülésznő. ${ }^{136}$ Idősebb korában, a kórházban Mária mamaként emlegették. Az általa világra segített újszülöttek száma kapcsán megjegyzi, hogy ugyan nem emlékszik pontosan, de a kórházban „ezer valahány száz" szülésnél volt jelen. ${ }^{137}$

A modern orvostudomány XVIII. század végi megszületésével egyidejüleg elterjedt a Michel Foucault által orvosi tekintetnek nevezett ellenőrzési mechanizmus. ${ }^{138}$ „A szem lesz a világosság forrása és letéteményese; rendelkezik azzal a hatalommal, hogy napvilágra hozza az igazságot. (...) A tekintet már nem redukálja, hanem megalapozza az egyént a maga redukálhatatlan tulajdonságaiban." ${ }^{139}$ Bár a jelenség évszázadok óta ismert volt, a Nagyatád környéki nők életében csak a XX. században jelentett változást. Az intézményben történő szülés lehetőséget ad az egészségügyi személyzet számára a női test feletti ellenőrzés gyakorlására. Ennek első állomása a szülőotthon, ahol - a fentiek tükrében jól látható módon - még erős a bábai/szülésznői dominancia.

A kórházi szülészeti ellátás kapcsán megjegyzendő, hogy az orvos-beteg viszony egyben egy hatalmi viszony is. ${ }^{140} \mathrm{~A}$ viszonyrendszer szereplői pedig társadalmilag és kulturálisan meghatározott szerepeket töltenek be, vagyis mind az orvos, mind a beteg (jelen esetben a szülő nő) normatív viselkedésmintákat követ. A hatalom birtokosa (orvos) folyamatosan rákényszerül önnön hatalmának reprezentációjára,

134 Ebböl az időszakból őrzött könyve: Ulbing István: Házi gondozás, betegápolás. Magyar Vöröskereszt, második kiadás, 1986.

135 Egészen hatvan éves koráig, 1987-ig dolgozott.

136 Kutatásom során bárkit kérdeztem idős, még élő szülésznőkröl, egyöntetüen őt nevezték meg, vagyis a közösségi emlékezetben máig jelen van alakja.

137 Horváth Mária életének 91. évében, 2018 nyarán elhunyt. Tárgyi és írásos emlékeit megőrizzük az utókor számára.

138 „E bíróság írja majd elő, milyen könyveket kell olvasni és mely műveket megírni; a kapott információk alapján kijelöli, hogy az uralkodó betegségek terén milyen gondozói tevékenységet kell foganatosítani; saját vizsgálódásai vagy külföldi munkák alapján közzéteszi, mit kell felvilágosult gyakorlatnak tartani. Az orvosi tekintet autonóm mozgást írva le körben jár egy téren belül, ahol megkettőződik és ellenőrzi önmagát; önállóan osztja el a hétköznapi tapasztalásnak a saját, nagyon messziröl átvett tudását, amelynek gyüjtője, egyszersmind elosztó központja." Foucault 2000. 134-135. (kiemelés tölem: S. F.)

139 Foucault 2000. 93.; 97.

140 Foucault meghatározásában „a hatalmi viszony más cselekvésekre ható cselekvés." Foucault 2002. 404. mely által fenntarthatóvá válik kiemelt pozíciója. ${ }^{141}$ Ennek megtartásához szüksége van egy másikra (szülö nő), akin keresztül érvényesül pozíciója. A hegemónia fenntartásához mindkét fél aktív jelenlétére (szerepjátszására) szükség van. ${ }^{142} \mathrm{Az}$ orvos-szülésznő viszony is társadalmi szerepekre épül, melyekhez kötődő viselkedésminták és szemléletmódok eltérő mivolta dinamikus kölcsönhatásban van egymással. Elmondható ugyanis, hogy a klasszikus, empátiára és beleérző képességre épülő szülésznői szerep mint társadalmi konstrukció nem valami „esszenciálisan női” képességek megtestesülése, hanem a hatalmi hierarchiában betöltött pozíció kifejeződése. ${ }^{143}$

A „női megérzés” konstruált mivolta a nők társadalomban betöltött tanult szerepével is magyarázható. A biológiai esszencializmust megkérdőjelező feminista irányzat azt állítja, hogy a nemek szerinti munkamegosztás nem valami eredendő nemi sajátosságokból fakad, hanem a szocializáció során belsővé tett képességekben gyökerezik. ${ }^{144}$ Ebben a keretben a nők „anyai ösztöne” is egy gazdaságilag, történetileg és szociokulturálisan meghatározott konstrukcióként, nem valami veleszületett biológiai sajátosságként értelmeződik. ${ }^{145}$

\section{Összegzés}

Jelen tanulmányban két somogyi bába munkássága alapján tártam fel a bábaság korabeli lokális gyakorlatát. Horváth Gyuláné Boli Irma tárgyi emlékei és bábanaplói által kirajzolódó kép és a helytörténeti források információi alapján bemutattam, milyen lehetett egy dél-somogyi bába élete a XX. század közepén. A mesterség átalakulásának megfigyeléséhez szükséges volt egy másik bába, Dudás Béláné Horváth Mária szakmai életútjának elemzése is. A nagyatádi szülöotthonban, majd később a kórházban dolgozó szülésznő-

141 A nyilvánosság és a hatalmi reprezentáció kérdéséről az uralkodó és udvartartása valamint férfi és nő viszonyában lásd: Habermas 1993. 12-14.

142 A hatalmi viszony fennállásának feltétele, hogy „a »másik« (ak felett a hatalmat gyakorolják) mindvégig teljes egészében cselek vő személyként legyen elfogadva." Foucault 2002. 405. (kiemelés tölem: S. F.) Ugyanitt jegyzi meg Foucault, hogy a kormányozni [conduire (vezet, kormányoz) - se conduire (viselkedik)] annyit tesz, mint „más emberek lehetséges cselekvési terét alakítani.” Habár a kórházi szülészeteket érő kritikában az egyik leggyakrabban megjelenő elem a szülő nő döntés- és/vagy cselekvésképtelensége, véleményem szerint ez nem zárja ki a hatalom foucault-i meghatározásának használatát, ellenkezőleg. Az indirekt vagy szimbolikus uralom természetéböl fakadó kettősséget példázza hogy miközben a nők látszólag cselekvéseket hajtanak végre (bemennek a kórházba, felmásznak a szülőágyra stb.) valójában nincs más lehetőségük, mint végrehajtani ezeket a cselekedeteket. Vagyis a számukra kijelölt cselekvési keretben mozognak. A kórház személyzet egyrészt cselekvő állampolgárokként bánik velük (jogi nyilatkozatok aláiratása) másrészt tudatában van a szülő nő alávetett pozíciójának, limitált mozgásterének. Ez a paradoxon hozzájárul az intézményrendszer müködési elveinek fenntartásához.

143 A nature vs. nurture vitáról lásd: Nagy 2014.

144 Bem 1993. 6-38. A biológiai esszencializmus című fejezet magyar fordítását lásd: Kende Anna - Vajda Róza (szerk.): Rasszizmus a tudományban 2008. 147-198.

$145 \mathrm{Az}$ anyai ösztön történeti, kritikai elemzéséről lásd: Badinter 1999. 
vel készített interjúk alapján megismerhettük az intézményben működő bábák világának egy szeletét.

Horváth Mária retrospektív narratívája, korabeli iskolai jegyzetei és első tankönyve ${ }^{146}$ alapján azt mondhatjuk, hogy az ötvenes évek elején formálódó szülésznői kultúra egyfajta átmeneti, hibrid szemléletmódon alapul a premodern és a modern születéskultúrák között. ${ }^{147}$ A premodern szüléskultúra ismertetőjegyei közé tartozik a női közösség kizárólagos szerepe, az individuális döntési lehetőség hiánya, a tudás hagyományozódása, valamint a test és a lélek egységén alapuló holisztikus szemléletmód. A nagyatádi szülőotthoni gyakorlatban még tetten érjük a hagyományosnak mondott bábasághoz köthető elemeket; látjuk még a megérzések, a női közösség szerepét és a gyerekágyi időszakra is kiterjedő figyelmet, de már jelen van a természetes folyamatokba való beavatkozások pozitív hatásába vetett hit és a technokrata szemléletmód racionalitása. Vagyis megjelennek a modern szüléskultúra attribútumai: az orvosi intézményrendszer ellenőrzése, a medikalizáció, a tekintélyelvűség valamint a test lélektől való radikális elválasztásán alapuló technokrata szemléletmód.

A születés helyének változása kapcsán láthatjuk tehát, hogy nincs lineáris fejlödési folyamat az otthoni szülésektől a kórházi felé haladva. Míg Magyarországon az 1950-es években kezdett általánossá válni a kórházban való szülés, látnunk kell, hogy Nagyatádon csak a hetvenes évek második felében, 1976-ban nyílt meg a városi kórház. Ezzel egy időben, 1977-től Geréb Ágnes elkezdte beengedni az apákat egy budapesti kórház szülőszobájába, amit az akkori protokoll szigorúan tiltott. ${ }^{148}$ Mikrotörténeti kutatásokkal bizonyítható, hogy az ötvenes-hatvanas években (van ahol később is) létezett otthoni szülés a magyar nyelvterület archaikusabb vidékein. Moldvában, az intézményrendszer kiépülésének hiányához kapcsolódóan, az 1990-es években Deáky Zita még talált működő, semmilyen egészségügyi képzésben nem részesült parasztbábákat. ${ }^{149}$ Eközben 1989-től Geréb Ágnes már „nem hivatalos" otthonszüléseket kísért a posztmodern, tudományos alapokon nyugvó bábai szemlélet alapján. ${ }^{150}$

A bábaság $X X$. századi átalakulása tehát egy meghatározó, de koránt sem progresszív folyamat. Tanulmányomban a forrásokban megjelenő szemléletmódok bemutatására és kritikai összehasonlítására koncentráltam. A bábaság mint női foglalkozás kérdésköre szorosan kapcsolódik a társadalmi nemek tanulmányának vizsgálati eredményeihez, ezzel egyben új perspektívába helyezve a mesterséget. Jelen kutatás csupán csepp a tengerben, de reményeim szerint hozzájárult a kortárs bábakutatások perspektívájának kiszélesítéséhez.

\section{Irodalom}

Acsády Judit 2014: A gondoskodás társadalmi konstrukciója. - Replika 85-86: 147-163

Assmann, Jan 1999: A kulturális emlékezet. Budapest, Atlantisz

Badinter, Elisabeth 1999: A szerető anya: az anyai érzés története a 17-20. században. Debrecen, Csokonai Kiadó

Basevi, Vittorio - Lavender, Tina 2014: Routine perineal shaving on admission in labour. - In: Cochrane Database of Systematic Reviews http://onlinelibrary.wiley.com/doi/10.1002/14651858. CD001236.pub2/full [Utolsó elérés: 2018.07.26.]

Bárth Dániel 2007: Avatottak és avatatlanok. Szempontok az asszonyi tisztátalanság mentalitástörténeti kérdéseinek vizsgálathoz. - In: Pócs Éva (szerk.): Maszk, átváltozás, beavatás. Vallásetnológiai fogalmak tudományos megközelítésben. 83-96. Budapest, Balassi Kiadó

Bárth Dániel 2005: Esküvő, keresztelő, avatás. Egyház és népi kultúra a kora újkori Magyarországon. Budapest, MTA-ELTE Folklór Szövegelemzési Kutatócsoport

Bem, Sandra 1993: The Lenses of Gender. New Haven, Yale University Press

Bősze Sándor (szerk.) 2001a: Nagyatád monográfiája I. Nagyatád, Nagyatád Város Önkormányzata

Bősze Sándor (szerk.) 2001b: Nagyatád monográfiája II. Nagyatád, Nagyatád Város Önkormányzata

Csonka-Takács Eszter 1999: Női tisztátalansági tabuk a magyar néphitben. - In: Küllős Imola (szerk.): Hagyományos női szerepek. Nők a populáris kultúrában és folklórban. 266-272. Budapest, Magyar Néprajzi Társaság, Szociális és Családügyi Minisztérium

146 Horn - Zoltán 1961

147 A különböző születéskultúrák részletes leírását lásd: Kisdi 2012. $2-5$
Csorba József 1857: Somogy vármegye ismertetése. Pest

Davis-Floyd, Robbie E. 1987: The Technological Model of Birth. - In: The Journal of American Folklore Vol.100. No.398: 479-495.

Deáky Zita 1994: „Szemelvájsz” volt tanítónk: Egy kunmadarasi bába működése a XIX. század második felében. - In: Ujváry Zoltán (szerk.): In memoriam Sztrinkó István. 421-430. Debrecen, Debreceni Egyetem Néprajzi Tanszék

Deáky Zita 1996: A bába a magyarországi népi társadalomban (18. század vége - 20. század közepe). Budapest, Centrál Európa Alapítvány

Deáky Zita 1999: Egy női szerep - közösségi feladatok és egyéni lehetőségek a bábamesterség tükrében. - In: Küllős Imola (szerk.): Hagyományos női szerepek. Nők a populáris kultúrában és folklórban. 46-56. Budapest, Magyar Néprajzi Társaság, Szociális és Családügyi Minisztérium

Deáky Zita 2002: A hivatásos és a hagyományos gyógyítás a magyar történeti forrásokban. Budapest, Osiris

Deáky Zita 2005: A női tisztaság és tisztátalanság. A menstruáció különböző aspektusai Magyarországon. - In: Keszeg Vilmos - Tötszegi Tekla (szerk.): Tanulmányok Gazda Klára 60. születésnapjára. (Kriza János Néprajzi Társaság Évkönyve 13.) 73-96. Kolozsvár, Kriza János Néprajzi Társaság

Deáky Zita - Krász Lilla 2005: Minden dolgok kezdte. A születés kultúrtörténete Magyarországon: XVI. - XX. század. Budapest, Századvég

148 Veiszer 2012. 59

149 Deáky 1999. 51

150 Kisdi 2013. 79 
Dorcsi Sándor - Juhász Sándor (szerk.) 1981: Tények és adatok. Nagyatád egy évtizedes fejlődése. Nagyatád, MSZMP Nagyatádi Városi Bizottsága

Douglas, Mary 2001: Purity and Danger. An analysis of the concepts of pollution and taboo. London and New York, Routledge, Taylor and Francis e-Library

Erdős Kamill 1957: Terhesség, szülés, gyermekágy, szoptatás a magyarországi cigányoknál. - In: Néprajzi Közlemények 2./3-4: 258263.

Foucault, Michel 2000: A klinikai orvoslás születése. Budapest, Corvina

Foucault, Michel 2002: A szubjektum és a hatalom. - In: Bókay Antal et al. (szerk.): A posztmodern irodalomtudomány kialakulása. 396409. Budapest, Osiris

Frazer, James G. 1998: Az aranyág. Budapest, Osiris

Györe Béláné et al. (szerk.) 2002: Múltidéző XII. Nagyatádi életrajzi kislexikon. Nagyatád, Városi Közművelődési Könyvtár

Györe Béláné et al. (szerk.) é.n.: Elödeink. Nagyatád

Greer, Germaine 2002: A kasztrált nő. Budapest, Corvina

Habermas, Jürgen 1993: A társadalmi nyilvánosság szerkezetváltozása. Budapest, Osiris

Horn Béla - Zoltán Imre 1961: A szülészet tankönyve. Budapest, Medicina Könyvkiadó, 3. átdolgozott és bővített kiadás

Juhász Katalin (szerk.) 2009: Tiszta sorok. Tanulmányok a tisztaságról és tisztálkodásról. (Documentatio Ethnographica 25.) Budapest, L'Harmattan

K. Horváth Zsolt 2016: A bundátlan Vénusz: a női testszőrzet biopolitikai mítoszai és az „eszményi test” politikai gazdaságtana 1-4. http://aszem.info/2016/11/aaa-bundatlan-venusz-1-resz/ [Utolsó elérés: 2018.07.26.]

Kalányosné László Julianna 1999: Terhesség és gyerekágy az őcsényi (Tolna megye) beás cigányoknál. - In: Várandósság, születés és gyermeknevelés a magyarországi kultúrákban. 151-158. Budapest, Magyar Pre-és Perinatális Pszichológiai és Orvostudományi Társaság

Kapros Márta 1986: A születés szokásai és hiedelmei az Ipoly mentén. Debrecen, Kossuth Lajos Tudományegyetem

Kisdi Barbara 2012: A női test dekolonizációja. A szülés posztmodern szemlélete. - In: Néprajzi Látóhatár 2012/3: 23-44.

Kisdi Barbara 2013: Mint a földbe hullott mag. Otthon szülés Magyarországon - egy antropológiai vizsgálat tanulságai. Budapest, L'Harmattan Kiadó

Kitzinger, Shiela 2005: The politics of birth. Amsterdam, Elsevier Butterworth Heinemann
Krász Lilla 2003: A bába történeti szerepváltozása a 18. századi Magyarországon. Budapest, Osiris Kiadó

Laczkó András et al. 1971: Nagyatád. Nagyatád, Nagyatádi Városi Tanács

Nagy Beáta 2014: Biológia vagy társadalom? Bevezető tanulmány a társadalmi nemek kérdésköréhez. - In: Kultúra és Közösség 2014/IV: 95-103.

Neményi Mária 1998: Cigány anyák az egészségügyben. Budapest, Nemzeti és Etnikai Kisebbségi Hivatal

Németh György 1992: Volt-e Ratkó törvény? - In: Társadalmi Szemle 1992/12: 81-92.

Ortner, Sherry B. 2003: Nő és férfi avagy természet és kultúra? - In: Biczó Gábor (szerk.): Antropológiai irányzatok a második világháború után. 195-212. Debrecen, Csokonai Kiadó

Pető Andrea 2005: Abortőrperek és „bajba jutott nők” 1952-ben. - In: Palasik Mária - Sipos Balázs (szerk.): Házastárs? Vetélytárs? Munkatárs? A női szerepek változása a 20. századi Magyarországon. 300-319. Budapest, Napvilág Kiadó

Reismann Adolf 1932: Magyar bábakönyv. Budapest, Magyar Királyi Állami Nyomda, harmadik, átdolgozott kiadás

Szathmáry Zoltán 1948: Szülésznők tankönyve. Budapest, Vallás- és Közoktatásügyi Minisztérium

Valuch Tibor 2002: Magyarország társadalomtörténete a XX. század második felében. Budapest, Osiris Kiadó

Veiszer Alinda 2012: Geréb Ágnes. - In: Ráadás 40-66. Budapest, Alexandra Kiadó

\section{Forrásjegyzék}

Bábairatok:

Horváth Gyuláné Boli Irma bábaasszony hagyatéka (Rinyaújlak, 1935-1953.): Nagyatádi Kulturális és Sport Központ - Nagyatádi Városi Múzeum. Leltári szám: 2014.1.1. - 2014.1.30. Digitális változat: https://hu.museum-digital.de/portal/index. php?t=serie\&serges=220 [Utolsó elérés: 2018.07.26.]

Riba Mária bába iratai (Balatonberény, 1930-1952.): Somogy Megyei Levéltár XIV.54.

Brávácz Józsefné bába iratai (Balatonberény, 1907-1938.): Somogy Megyei Levéltár XIV.55.

Újságcikkek:

Somogyi Néplap 1951. VIII. évf. 233: 1.; 1953. X. évf. 75: 5.; 1957. XIV. évf. 303: 1.; 1958. XV. évf. 288: 6. 
